\title{
Tulane
}

\author{
Tulane Economics Working Paper Series
}

\section{Rethinking Local Government Reliance on the Property Tax}

\author{
James Alm \\ Department of Economics \\ Tulane University \\ New Orleans, LA \\ jalm@tulane.edu
}

\author{
Robert D. Buschman \\ Fiscal Research Center \\ Andrew Young School of Policy \\ Studies \\ Georgia State University \\ Atlanta, GA \\ rbuschman1@gsu.edu
}

\author{
David L. Sjoquist \\ Economics Department \\ Georgia State University \\ Atlanta, GA \\ sjoquist@gsu.edu
}

Working Paper 1215

July 2012

\begin{abstract}
Historically, local governments in the United States have relied on the property tax as one of their main sources of own-source revenues. However, the recent collapse of housing prices and the resulting negative impact on local government budgets suggest that it may be opportune to rethink this strategy. In this paper we document the overall decline in property values in the United States in recent years, and we find that the impact is in the aggregate negative but that the impact varies significantly by state and by locality. We also examine the impact on local government revenues, and we again find substantial regional and local variation. Indeed, our data indicate that substantial numbers of local governments seem to have avoided the significant and negative budgetary impacts seen most clearly for state and federal governments, at least to date. We then focus specifically on the State of Georgia, in order to determine the ways in which local governments have responded to the economic recession. Our empirical analyses indicates that there are several factors causing changes in property tax revenues, but the dominant factor is changes in housing prices, with some significant lags. We conclude that local government reliance on the property tax has in fact been an advantage for many local governments in the current economic environment, and that such reliance is likely to continue in at least some form for the immediate future.
\end{abstract}

Keywords: property tax, state and local finance, tax limitations, assessment, tax base elasticity JEL: H2, H7, R3, R5 


\title{
Rethinking Local Government Reliance on the Property TaX
}

\author{
James Alm* \\ Tulane University \\ Robert D. Buschman \\ Georgia State University \\ David L. Sjoquist \\ Georgia State University
}

\begin{abstract}
Historically, local governments in the United States have relied on the property tax as one of their main sources of own-source revenues. However, the recent collapse of housing prices and the resulting negative impact on local government budgets suggest that it may be opportune to rethink this strategy. In this paper we document the overall decline in property values in the United States in recent years, and we find that the impact is in the aggregate negative but that the impact varies significantly by state and by locality. We also examine the impact on local government revenues, and we again find substantial regional and local variation. Indeed, our data indicate that substantial numbers of local governments seem to have avoided the significant and negative budgetary impacts seen most clearly for state and federal governments, at least to date. We then focus specifically on the State of Georgia, in order to determine the ways in which local governments have responded to the economic recession. Our empirical analyses indicates that there are several factors causing changes in property tax revenues, but the dominant factor is changes in housing prices, with some significant lags. We conclude that local government reliance on the property tax has in fact been an advantage for many local governments in the current economic environment, and that such reliance is likely to continue in at least some form for the immediate future.
\end{abstract}

JEL Classifications: H2, H7, R3, R5.

Keywords: property tax; state and local finance; tax limitations; assessment; tax base elasticity.

* Corresponding author: James Alm, Department of Economics, Tulane University, 208 Tilton Hall, 6823 St. Charles Avenue, New Orleans, LA 70118 (phone 1504862 8344; fax 1504865 5869). An earlier version of this paper was presented at the Urban Institute-Brookings Institution Tax Policy Center and the Lincoln Institute of Land Policy Conference, "Effects of the Housing Crisis on State and Local Governments", in May 2010. We would like to thank John Matthews and Lakshmi Pandey for their computer assistance with this work, Chris Pece for providing U.S. Census Bureau data, and Dan McMillen and an anonymous referee for many helpful comments. Email addresses: jalm@tulane.edu (Alm); rbuschman1@gsu.edu (Buschman); sjoquist@gsu.edu (Sjoquist). 


\section{Introduction}

There is little doubt that the "Great Recession" that lasted officially from December 2007 to June 2009 continues to have major effects on the fiscal position of federal and state governments. At the federal level, the deficit grew from $\$ 459$ billion in FY2008 to $\$ 1.4$ trillion in FY2009, which at the time was the largest dollar magnitude in history and also the largest as a percentage of GDP since the end of World War II; even with economic recovery, the federal deficit was \$1.3 trillion in FY2010 and \$1.6 trillion in FY2011, and the current Administration budget proposal projects a FY2012 deficit at \$1.1 trillion, with high deficits projected for the next decade (Office of Management and Budget, 2012). At the state level, the recession has caused the steepest decline in state tax revenues in memory (Boyd and Dadayan, 2009; Mikesell and Mullins, 2010), and states have responded mainly by making major cuts in spending (The Nelson A. Rockefeller Institute of Government, 2010; Center on Budget and Policy Priorities, 2010). Despite these cuts, state budget deficits for the current and immediately future years remain at alarmingly high levels.

How have local governments been affected? It is widely perceived that local governments have also been severely affected by these same forces. The bursting of the housing bubble and the resulting decline in economic activity should, it is believed, have a serious negative impact on local governments, especially those dependent on local property taxes as a major source of revenues. It is this issue that we examine here. We first use data from the U.S. Census Bureau to examine the trends of local government revenues (especially the property tax) over the last decade. We find that there is great diversity in the experiences of local governments over this period and especially in the immediate past several years. However, we also find that the widespread expectation that most local governments have suffered the same fate as state and 
federal governments is not generally supported, at least to date. We then focus more specifically on the State of Georgia by examining detailed information on property tax assessments and property tax rates for local school districts in the state. We find that property values declined in Georgia (as in many other parts of the country), but we also find that local school districts were in many cases able to maintain a steady pattern of collections by increasing millage rates. Our empirical analyses indicates that there are several factors causing changes in property tax revenues, but the dominant factor is changes in housing prices, with some significant lags. We conclude that local government reliance on the property tax rather than more elastic revenues sources like income, sales, and excise taxes may in fact have been a significant advantage for local governments in the current economic situation.

\section{Housing Prices and Local Government Revenues}

Local governments in the United States typically rely on several main sources of ownsource revenues, including individual income taxes, general sales taxes, specific excise taxes, fees and charges, and local property taxes. Of these, the dominant source is by far the property tax. In 2008 , local property taxes accounted for roughly three-fourths of total local government tax revenues and for nearly one-half of total local own-source revenues (including fees and charges) ${ }^{1}$

The Great Recession has obviously had serious and negative effects on the level of economic activity, and these effects have in turn depressed revenues of most governments that are reliant upon taxes whose bases vary closely with economic activity, like income and sales taxes. However, an important feature of the property tax is that its base (e.g., assessed value) does not automatically change over time. With the property tax, any increase in the market value

\footnotetext{
${ }^{1}$ See http://www.census.gov/govs/estimate.
} 
of housing does not necessarily translate into an increase in assessed value, and so into an increase in revenues, in the absence of a formal and deliberate change in assessment. Lags in these re-assessments, combined with caps on the amount by which assessed values can be changed in any given year and with deliberate changes in millage rates, mean that changes in the overall level of economic activity that may affect housing values may not actually affect property tax revenues in any immediate or obvious way, unlike other taxes that are much more closely linked to economic activity. ${ }^{2}$

More generally, there are several channels by which changes in housing values driven by changes in economic activity may affect local government tax revenues (Anderson, 2010; Lutz, Molloy, and Shan, 2010). The most obvious is of course via the property tax, although this link is (as noted) neither immediate nor automatic. Other channels are more closely linked to economic activity. Real estate transfer taxes depend upon the volume and the value of real estate transactions, although these taxes are of relatively little importance. Less direct channels include those affected by declines in housing values. For example, a decline in housing values may depress new housing construction, thereby reducing sales tax revenues generated by the materials used in construction. The decline in home construction and the resulting fall in employment may also reduce income taxes. Finally, a decline in housing values may reduce consumer expenditures (and so sales tax revenues) via wealth effects. ${ }^{3}$

As a general framework in which these channels might be modeled, consider a simple setting. Suppose a local jurisdiction has multiple tax sources, each generating revenues defined as the product of a tax rate $t$ and a tax base $B$. Denoting each with a subscript $i$, then total

\footnotetext{
${ }^{2}$ The assessment process is analyzed in detail by Diaz (1990), Quan and Quigley (1991), Wolverton and Gallimore (1999), and McAllister et al. (2003).

${ }^{3}$ For empirical estimates of these wealth effects, see Attanasio et al. (2009), Bostic, Gabriel, and Painter (2009), and Campbell and Cocco (2007).
} 
revenues $R$ equal $R=\sum_{i} t_{i} B_{i}$. Suppose now that either the tax rate or the tax base of each tax changes. Then the percentage change in tax revenues equals:

$$
\Delta R / R=\sum_{i} s_{i}\left[\Delta B_{i} / B_{i}+\Delta t_{i} / t_{i}\right]
$$

that is, the percentage change in tax revenues equals the share $s_{i}$ of each tax in total revenues times the sum of the percentage change in the tax base plus the percentage change in the tax rate for each of the $i$ taxes. A tax that has a small share of total revenues obviously has a smaller impact on changes in revenues, even if its base and/or rate change significantly; conversely, a tax (like the local property tax) that is a major source of revenues can have a large impact on revenues even if its base and/or rate change by small amounts. Suppose finally that the tax base of each tax is some function of the level of economic activity, denoted $Y$. With a change in the level of economic activity, the percentage change in any tax base due to a changed economic environment can be written as $\Delta B_{i} / B_{i}=\varepsilon_{i}(\Delta Y / Y)$, where $\varepsilon_{i}$ is the elasticity of tax base $i$ with respect to the level of economic activity. The percentage change in total revenues now becomes:

$$
\Delta R / R=\sum_{i} s_{i}\left[\Delta B_{i} / B_{i}+\varepsilon_{i}(\Delta Y / Y)+\Delta t_{i} / t_{i}\right]
$$

where $\Delta B_{i} / B_{i}$ now represents the deliberate administrative or policy change in the tax base of tax $i, \Delta t_{i} / t_{i}$ represent the administrative change in tax rate $i$, and $\varepsilon_{i}(\Delta Y / Y)$ denotes the (automatic) change in the tax base of tax $i$ stemming from its link with economic activity. This equation summarizes the various channels by which revenues - whether of a single tax or a collection of taxes - are affected by a change in policy actions or in external circumstances. Revenues can change if the tax rate(s) or the tax base(s) changes; revenues can also change if the level of economic activity changes, provided that the tax base(s) is linked in some way to economic activity, as measured by $\varepsilon_{i}$. If the tax base cannot change, either because it is not responsive to economic activity, because it requires a deliberate but unforthcoming policy action, or because it 
is administratively constrained, then the only remaining source of a change in revenues is from a change in the tax rate(s).

Given the difficulty of disentangling these various channels, the actual impact of housing values on local tax revenues remains somewhat illusive. Lutz (2008) estimates that it takes several years (generally about three years) for changes in housing prices to feed through in any significant way to property tax revenues. His empirical results suggest a long-run elasticity of property tax revenue with respect to home prices of only 0.4 , in part because it takes time for local officials to adjust assessed values to market values and in part because local officials generally reduce millage rates in response to increases in housing prices. He also finds asymmetric responses of property tax revenues to increases versus decreases in home prices. Relatedly, Lutz, Molloy, and Shan (2010) present evidence that the non-property tax channels have been of relatively little importance in their effects on state and local government revenues, either in the housing market boom/bubble of the early-to-mid-2000s or in the more recent collapse of housing prices during the Great Recession.

Doerner and Ihlanfeldt (2010) focus more directly on the effects of house prices on local government revenues, using detailed panel data on Florida home prices during the 2000s. They conclude that changes in the real price of Florida single-family housing have an asymmetric effect on government revenues: price increases do not raise real per capita revenues, but decreases tend to dampen revenues. Like Lutz (2008), they conclude that these asymmetric responses are due largely to lags between changes (positive or negative) in market prices and assessed values, to caps on assessment increases, and to decreases in millage rates in response to increases in home prices. They also find that the indirect links between home prices and local government revenues (e.g., estate transfer taxes, sales tax revenues on home construction 
materials, income taxes on construction-related employment, wealth effects from home values on sales tax revenues) are generally small, with the exception of an additional channel via impact fees, which are of some importance for many Florida local governments and which are affected in significant ways by changes in home prices.

Some other recent work focuses more specifically on the effects of property tax limitations on local government revenues. ${ }^{4}$ Skidmore and Scorsone (2010) analyze Michigan municipalities, and find that the combination of property tax limitations (Proposal A) and housing price declines have been the major factors in the deterioration of local fiscal conditions. Wallin and Zabel (2010) likewise conclude that the impact of the Massachusetts Proposition 21/2 on local revenues was significant and negative, and has led to a number of cities and towns attempting override votes. ${ }^{5,6}$

Despite the many insights generated by this work, there remain important gaps in our understanding of the link between housing prices and local government revenues. The next sections discuss our approach for filling in these gaps. In particular, we examine recent trends in housing values at the national, state, and local levels, and we also examine the subsequent impacts on property tax revenues, also at the regional and local levels. Finally, we examine a specific state, Georgia, where we have much more detailed information on local property values

\footnotetext{
${ }^{4}$ There is a large literature on the effects of tax limitations. For useful general discussions, see Preston and Ichniowski (1991), O'Sullivan, Sexton, and Sheffrin (1995), and Dye and McGuire (1997). The entire issue of Public Budgeting \& Finance (Volume 24, Number 2, December 2004, "Tax and Expenditure Limitations: A Quarter Century after Proposition 13") is devoted to tax limitations.

${ }^{5}$ For other, earlier analyses of the Massachusetts property tax limitation, see Ladd and Wilson (1982), Cutler, Elmendorf, and Zeckhauser (1999), and Wallin (2004).

6 There are other examples of state-specific studies. For example, see Dye, McGuire, and McMillen (2005) and Dye, McMillen, and Merriman (2006) for analyses of the response of local governments in Illinois to assessment growth caps. Also, Cornia and Walters (2006) consider an alternative policy in Utah for limiting property tax increases called "full disclosure", which informs property owners about any increases in property taxes that follow property reappraisals.
} 
and other local variables, to determine how the Great Recession has affected local governments. In all cases, we attempt to explain the various factors that have affected property tax revenues.

\section{Data and Sources}

Because we examine both national and Georgia trends, we have several datasets. For national trends, we obtained quarterly property tax revenue data extracted from the U.S. Census Bureau Quarterly Summary of State and Local Government Tax Revenue, for each quarter 1998 through 2009. These data are a custom tabulation at the individual governmental unit level, collected by the Census Bureau from a survey of county, city, and township governments as well as from school districts and special taxing districts (e.g. fire districts). We refer to these data as the "Quarterly Collections Data", or QCD. For the regression analysis, we restricted the final dataset to counties, cities, townships and independent school districts, and we dropped units where data were imputed or missing for any period. The resulting dataset contains 396 districts representing 19 states. $^{7}$

Another data source for our analysis of national trends comes from property tax collections reported by the Census Bureau by state by fiscal year through 2008 on its webpage. We refer to these data as the "Census data".

It should be emphasized that these two datasets tell similar but not identical stories about national trends. Figure 1 compares, using the complete file, the QCD property tax collections for the U.S. with the Census data, comparing fiscal year to the same calendar year (i.e., FY 1998 for the Census data and 1998 for the QCD) for each year, staring with 1998 and extending to the most recent year available. These data track closely, particularly in the more recent years for the

\footnotetext{
${ }^{7}$ States represented include Connecticut, Florida, Georgia, Illinois, Kentucky, Massachusetts, Michigan, Missouri, New Jersey, New York, Oregon, Pennsylvania, Rhode Island, South Carolina, Tennessee, Texas, Vermont, Washington, and Wisconsin.
} 
Census data. (For 1998, the data for South Dakota are missing for the QCD, so we excluded South Dakota from the Census data.) Some difference is expected since one dataset uses fiscal years and the other uses calendar years. Figure 2 shows the percentage change in the two series, and there are some large differences in the growth rates implied by the two series. These trends are discussed in section IV.

For Georgia trends, we obtained from the Georgia Department of Revenue the annual property tax base (referred to as "Net Digest" in Georgia) for each of the 180 school districts in Georgia for 1997 through 2009. We also obtained property tax millage rates, together with and local and state source revenues, for all school districts for 1999 through 2009 . The base is as of January $1^{\text {st }}$ of the respective year. The millage rate is set in the spring with tax bills being paid in the fall, the revenue from which would be reported in the following fiscal year. (School districts are on a July $1^{\text {st }}$ to June $30^{\text {th }}$ fiscal year.) Thus, the 2009 base would generate revenues for FY 2010. Trends in these variables are discussed in section V.

\section{$\underline{\text { IV. National, State, and Local Trends in Property Tax Collections }}$}

As shown in Figure 1, overall collections of local property taxes rose steadily over the last decade to about $\$ 440$ million in 2009 , roughly doubling over this period. The annual percentage change in local collections has always exceeded 4 percent, and has often been even greater (Figure 2). It is especially striking that even in the last two years the growth rate has

been greater than 4 percent. Real per capita collections also rose from $\$ 1000$ per capita in 1998 to nearly $\$ 1400$ per capita in 2009 (Figure 3).

These national trends hide enormous state variation. Charts 1 to 4 show the annual percentage change in local property tax collections by state, beginning in 2006 . To construct 
these charts, we used the QCD. We weighted the collections from each jurisdiction, summed over the four quarters of the calendar year, and aggregated by state.

Charts 1 to 3 show the weighted growth rates for the individual periods 2006-2007, 2007-2008, and 2008-2009, and Chart 4 shows the cumulative weighted growth rates over the 3 years; charts using unweighted data show the same patterns. Even in the most recent period (2008-2009), well over half of the states experienced a growth in property tax revenues (Chart 3). Those states that suffered a loss in revenues tended to be concentrated in the southeast and somewhat erratically in the midwest and the northeast. For the entire 3 year period, only 12 states experienced a decline in revenues (Idaho, North Dakota, Texas, Michigan, Indiana, Ohio, Kentucky, Tennessee, South Carolina, Florida, Pennsylvania, and Maine); see Chart 4.

In short, our data indicate that substantial numbers of local governments have avoided the significant and negative budgetary impacts seen most clearly for state and federal governments. An important qualification here is that these negative effects may obviously still materialize in the future.

As a preliminary investigation of factors that might explain differences in the growth rates of property tax collections between 2008 and 2009, we consider two factors: assessment limitations and housing price changes. In states with assessment limitations, the taxable value based on the limited assessed values may be below the taxable value based on market value. Thus, when market value falls, it may well be that taxable value is not affected. If we examine a simple plot of the percentage change in property tax collections between 2008 and 2009 by state for states with and without statewide assessment limitations, we see little correlation between collections and limitations. The presence of property tax assessment limits did not prevent increases in property tax revenues, but also did appear to prevent decreases in property tax 
revenue. A number of jurisdictions with no limits experienced significant declines in property tax revenues. Indeed, those jurisdictions with limits in most all cases had increases in revenues.

As for changes in housing values, we use the housing price index by state from the Federal Housing Finance Agency to construct the annual percent change in housing prices. Again, a simple plot of the percentage change in housing prices and in property tax collections for 2008-2009 reveals little correlation between changes in the index of housing prices and growth in property taxes.

To examine more systematically the factors affecting property tax revenues, we use the Quarterly Collections Data (QCD) from the U.S. Census Bureau Quarterly Summary of State and Local Government Tax Revenue, as described earlier. Recall that for the regression analysis we restricted our data to counties, cities, townships and independent school districts, and we dropped units with imputed or missing data. Our final data set consists of 396 government units in 19 states. Of these, 377 units are part of a Metropolitan Statistical Area (MSA) defined by the Census Bureau, with 61 MSAs represented. Another 8 units are part of a Micropolitan Statistical Area (Micro-SA, 5 represented), and 11 units are in neither an MSA nor a Micro-SA.

Several caveats are worth noting about these QCD data. First, the initial, full sample is not a random sample of government units, and is subject to non-response and other errors associated with surveys and censuses. Second, our elimination of some units raises the possibility of selection bias if the occurrence of imputed or missing data is not random. Third, our examination of the data suggested that there is reason to suspect reporting or recording errors. For 71 observations (out of 3,168), reported revenue more than doubled from the prior year, and for 34 of those observations revenue more than tripled. For another 55 observations, reported revenue fell by more than 50 percent from the prior year. In total, 65 government units 
reported these types of extreme revenue swings (e.g., greater than 100 percent increases, greater than 50 percent decreases, or both). These caveats notwithstanding, we believe that these data offer a unique opportunity to analyze property tax revenue changes across numerous states at the individual governmental unit level, enabling us to examine variations across individual units that are concealed in aggregated, state-level data.

We use the basic framework discussed earlier, in which the percentage change in property tax revenues depends upon administrative changes in the tax base, changes in the tax rate, and changes in economic conditions.

For our dependent variable, we calculate the annual percent change in property tax revenues by first summing quarterly data by calendar year for each unit to get the annual revenues and then by using the annual data to calculate the annual percent change for 2000 to 2009.

We attempt to explain the annual percent change in property tax revenues with several explanatory variables. We include the annual percent change in home values on the MSA level for units associated with an MSA, or on the state level for units that are not in an MSA. Changes in home values are derived from Freddie Mac's Conventional Mortgage Home Price Index (CMHPI), which is reported quarterly at the MSA and state levels. ${ }^{8}$ It is expected that a change in housing prices is one channel through which changes in the economy would affect property tax revenue. We use the lagged percent change in the CMHPI in the regressions to reflect changes prior to the given fiscal year.

In addition, based on tabulations from Haveman and Sexton (2008) and Hoyt, Coomes, and Biehl (2009), we create a dummy variable to indicate whether the unit is in a state with statewide property tax assessment limits because these limits reduce the ability of local

\footnotetext{
${ }^{8}$ Further information on the CMHPI data can be found online at http://www.freddiemac.com/finance/cmhpi/.
} 
governments to increase assessments as property values rise. Seven of the 19 states and 168 of the 396 governmental units in our final dataset have statewide assessment limits. ${ }^{9}$ We expect that in states with assessment limits property tax revenues would be less responsive to home values because, in periods of rapidly rising market values, assessed value increases are constrained by law. If assessments are unable to keep pace with market values in a rising market, then in a subsequent falling market, home values may fall for a time before impacting assessments. To test this hypothesis, we include an interaction term equal to the assessment limits dummy variable multiplied by the percent change in the CMHPI.

We control for local economic growth using changes in personal income at the county level, as reported in the Bureau of Economic Analysis Regional Economic Accounts Data. ${ }^{10}$ Specifically, we use the annual percent change in per capita personal income for the year prior to the revenue change.

Finally, we control for population growth using the percent change in population at the local government unit level (e.g., at the township, city, or county level as appropriate). For units that are school districts, we use population for the closest matching Census area (e.g., the county for county-wide systems, or one or more townships falling within a district's boundaries). ${ }^{11} \mathrm{We}$ expect both income and population growth to have a positive effect on property tax revenues, ceteris paribus, though any income effect would likely be of a longer-term nature that may not be reflected in estimates based on data in year-to-year percent changes.

The data cover the years 2000 through 2009 (or 2001 to 2009 in changes). To gauge whether revenues responded differently to home values and other variables in the recent housing-

\footnotetext{
${ }^{9}$ These states are Florida, Michigan, New York, Oregon, South Carolina, Texas, and Washington.

${ }^{10}$ See the Bureau of Economic Analysis Regional Economic Accounts Data, available online at http://www.bea.gov/.

${ }^{11}$ Population data are from the U.S. Census Bureau Population Estimates program, available online at http://www.census.gov/popest/estimates.html.
} 
led economic downturn, we also run regressions including terms in which the relevant variable is interacted with a dummy variable equal to one for years after 2006 and zero otherwise.

Table 1 provides summary statistics for the data, and Table 2 includes regressions results, beginning with OLS results for the entire dataset and the restricted dataset, excluding the 65 units with likely erroneous revenue data. ${ }^{12}$ Columns 3 through 6 of Table 2 present results of alternative regressions using panel-corrected standard errors (PCSE) to correct for possible autocorrelation and correlation across panels, and also using fixed effects with cluster-robust standard errors, clustering on MSA/Micro-SA. ${ }^{13}$

Table 1 shows that, except for the property tax revenues, there is little difference in the variable means and standard errors between the full dataset of all units and the restricted set excluding the 65 units with likely erroneous revenue data, suggesting that the excluded units do not differ significantly from the included ones in terms of the explanatory variables. However, the first two columns of Table 2 show significant differences in results when these 65 units are included or excluded in OLS regressions. When they are included (column 1), coefficient estimates on all the explanatory variables are large in magnitude, often with unexpected signs, but nowhere significant. When these units are excluded (column 2), we see a modest positive revenue effect from changes in home values, with a coefficient estimate of 0.13 and a p-value of 0.024 , and a roughly one-to-one relationship with population changes (an estimate of 1.11 and a p-value of 0.000). The positive but insignificant estimate on the assessment limits interaction

\footnotetext{
${ }^{12}$ Note that the $\mathrm{R}^{2}$ values reported for the regressions in Table 2 are somewhat low, for several reasons. Recall that the dependent variable in these regressions is the percentage change in property tax revenues and not its level. The data are transformed from levels to make the data stationary, and it is common for such transformations (e.g., through differencing, de-trending, or seasonal adjustment) to result in low $\mathrm{R}^{2}$ values. Also, the data represent a diverse set of government types drawn from widely different states with very different institutional features. In pooled regressions these unobserved differences are reflected in the residuals; in fixed effects models they are removed by the fixed effects transformation and so do not contribute to the model or the explained sum-of-squares, again resulting in low $\mathrm{R}^{2}$ values.

${ }^{13}$ The units that are not in an MSA or a Micro-SA are all in the same county and are treated as a cluster.
} 
term suggests assessment limits do not make revenues less responsive to home values. The positive estimate on per capita income is also not statistically significant. The PCSE model in column 3 produces very similar results to those in column 2.

Column 4 of Table 2 adds fixed effects and cluster-robust standard errors to the basic OLS model, producing somewhat larger estimates for the home value and income coefficients, although the income variable remains statistically insignificant. The estimated effect of population changes is slightly smaller (0.75 with a p-value of 0.024) than in the OLS and PCSE estimations. Assessment limits again show no apparent effect.

Columns 5 and 6 of Table 2 attempt to gauge whether the effects of the explanatory variables appear to differ in the three years since the peak in home values around 2006. Column 5 uses a dummy variable to indicate years after 2006, interacted with the home value, income, and population change variables; column 6 estimates the column 4 model using only 2007 through 2009 data. Although the interaction terms do not show statistically significant estimates in column 5, the signs and magnitudes of the home value and population interaction terms are both negative and comparable in absolute value to the estimates on the underlying variables, thereby suggesting that revenues became less responsive to home value and population changes in the recent three years compared to the prior six years. Similarly, column 6 shows statistically insignificant estimates for home value and population changes in the 2007-2009 period. Column 6 also shows a positive and significant estimated income effect that did not appear in the previous model results. It may be that the effect of the economic downturn on local property tax revenues is more closely correlated with its effect on incomes than home values, even though the downturn itself may have been driven by declining home values. 


\section{A Case Study: Property Tax Collections in the State of Georgia}

As noted earlier, we use data from the Georgia Department of Revenue on the annual property tax base and on annual property tax rates for each of the 180 school districts in Georgia for 1997 through 2009. In addition, we use data from the Georgia Department of Education on total local source revenues for school districts for 1999 through 2009 . We also use property tax liability by school district for 2006-2009 for a preliminary discussion of trends over this period, although we are missing levy data for 8 school districts for 2009.

Georgia is broadly similar to other states in the local government practice of and reliance upon property taxation, although there are some distinctive Georgia features. Property tax assessment is conducted only by county governments in Georgia. Property tax bases are all evaluated by the state every year to determine if they are at the appropriate assessment level, which is legally set at 40 percent; if the assessment is below 35 percent, then a penalty is imposed. ${ }^{14}$ The state conducts a systematic review of each county's property tax base on a threeyear cycle. If deficiencies are found and if the county does not fix the deficiencies, then the Commissioner of Revenue can withhold certain grants and impose a $\$ 5$ per parcel penalty. Over the period 2000 to 2009 , the average assessment ratio trended slightly up, and ranged from 36.5 percent to 37.9 percent.

Georgia has very few property tax limitations. School district boards can generally set their property tax rates without voter approval. The only exception is that the property tax rate for county school districts cannot exceed 20 mills without voter approval; only one district reached that limit during the period of our analysis. Also, there is no general assessment limitation, although one county has an assessment freeze on homesteaded property. Note that in

\footnotetext{
${ }^{14}$ If the actual assessment ratio is less than 36 percent, then the county is required to pay the difference between the actual property tax revenue that the state collects from its 0.25 mill property tax rate and the level that the state would have collected if the digest had been assessed at 40 percent.
} 
2009 the State of Georgia imposed a temporary freeze on assessments across the state, but that would affect property tax revenue only in school year/fiscal year 2010, and thus does not affect our data.

State and local school districts contribute about equal amounts of revenue for K-12 education. The bulk of the grant to local districts is through a foundation program; the state has a small equalization grant program as well. ${ }^{15}$ There were no changes in the nature of the funding formula during the period of our analysis.

Local governments in Georgia rely on property taxes somewhat less than the national average. In 2008, property tax revenue as a share of total taxes for local governments was 65.1 percent in Georgia compared to 72.3 percent of the U.S., and property taxes as a percentage of total local government taxes ranged from 40.1 percent for Louisiana to 98.7 percent for Maine. ${ }^{16}$ In terms of school funding, Georgia relies somewhat more heavily on non-property taxes than the average state. Ignoring the 9 states that either have essentially a state school system or that do not have independent school districts, property taxes as a share of local revenue in 2008 were 68.9 percent for the U.S. but only 64.9 percent for Georgia. The property tax share across these 41 states ranged from 34.9 percent in Louisiana to 90.1 percent in Illinois. Georgia ranks $24^{\text {th }}$ among the 50 states in terms of local government taxes per capita, and $33^{\text {rd }}$ in terms of property taxes per capita (Bourdeaux and Jun, 2011).

Figure 4 shows the growth rates in the real aggregate property tax base over the period 1997 through 2009. (Note that the growth from 2008 to 2009 is based on the same set of school districts because the 2009 data exclude 8 districts.) As can be seen, the growth rate declined following the 2001 recession, reaching a low growth rate of 2.45 percent for 2003 to 2004, which

\footnotetext{
${ }^{15}$ For a detailed description of Georgia school funding program, see Rubenstein and Sjoquist (2003).

${ }^{16}$ Revenue data are from 2008 State and Local Government Finances, U.S. Census Bureau, available online at http://www.census.gov/govs/estimate/.
} 
was only slightly larger than the growth rate of 2.11 percent for 2007 to 2008 . The growth in the real base became negative for 2009 .

Figure 5 shows the annual growth rate in real aggregate property tax base and property tax liability for school districts between 2006 and 2009. As can be seen, the growth in property tax liabilities is less than the growth in the tax base for 2007 and 2008, implying that tax rates fell each year. For 2009, the aggregate property tax base and tax liability both fell, but the liability fell by less, suggesting the school districts increased property tax rates on average. We do not have any information on the property tax base for 2010 other than newspaper reports about budget cuts, largely from metro Atlanta. Judging from these accounts, it appears that the property tax base and the expected property tax liabilities will decline for 2010, in the absence of adjustment of millage rates.

Of course, statewide aggregates may mask considerable variation across the districts. Figure 6 is a box plot showing the distribution of tax base changes (or percent change/100) for Georgia's 180 school districts each year from 1998 through 2009. For each year, the shaded box shows the interquartile range (IQR) from the $25^{\text {th }}$ to the $75^{\text {th }}$ percentile, with the median value indicated by a line dividing the box; the "whiskers" show the range of the lowest and highest quartiles, excluding extreme values more than 1.5 times the IQR above the $75^{\text {th }}$ or below the $25^{\text {th }}$ percentile. As Figure 6 shows, there was considerable variation in tax base changes (especially in 2001 and again in 2006-2007) and always a modest portion of districts experiencing declines in any given year, even while the general pattern for the middle quartiles is consistent with the statewide aggregates in Figure 4. Notably, however, there is much less variation across districts in 2008 and especially in 2009 where the median tax base change was zero percent and the IQR 
was only 3.5 percentage points (from -1.6 percent to 1.9 percent) compared to 10.1 percentage points in 2007 .

Figure 7 shows the distribution of millage rate changes (again as percent change/100) each year from 2000 through 2009 with the mean percent change overlaid on the box plot. Figure 8 shows the counts of systems raising, lowering, or leaving millage rates unchanged over the same period. As Figure 7 shows, while the median change in millage rates was zero every year, the distribution was skewed to the positive from 2002 through 2005 and again for the latest two years, while the mean change was negative in 2001 and 2007. There has also been considerably less variation across districts in millage rate changes in the last two years than in earlier periods. A plurality of districts left rates unchanged in six of the ten years and nearly a two-thirds majority left them unchanged in 2009 despite the decrease in the property tax base (Figure 8). About the same number of systems increased their rates in 2009 (39 districts) as in 2008 (41 districts). A plurality reduced rates in 2000, 2001, and 2007, and a plurality increased rates only in 2003.

Figure 9 shows the simple correlation between the growth in the property tax base and the change in the property tax rate each year from 2000 through 2009 . For most years, there is a significant negative correlation between the growth in the property tax base and the change in the property tax rate, suggesting that districts that had a large percentage increase in the property tax base were inclined to lower their property tax rate, while those districts with a small or negative change in the base were inclined to raise the rate. Property tax revenues, driven by changes in the tax base and rate, make up the bulk of local source revenues for operations and maintenance of school districts in Georgia. Given a desired level of local source revenues and the realized changes in the tax base, it should not be surprising to find a negative relationship between the tax 
rate and the tax base. However, for 2009 there is little correlation between tax rate and tax base changes as the vast majority of districts left millage rates unchanged. Perhaps school boards decided, in light of the economic conditions, that they should not raise millage rates. (Note that there was also little correlation between tax rate and tax base changes for 2005, although districts were much more evenly split between raising, lowering, or leaving tax rates unchanged.)

To better understand the relationships between local source school revenues, the tax base, and tax rates, we examine more systematically the factors affecting local source revenues and those driving tax rate changes in Georgia. Similar to our earlier econometric analysis of local property tax revenues for governments in the QCD sample, we estimate regressions of percent changes in local source revenues on income and population growth rates, along with change in the property values and changes in education funding from state revenues.

Local revenue figures are on a July-June school (fiscal) year basis, the Net Digest is as of January $1^{\text {st }}$, and income and population are on a calendar year basis. Thus, local revenue changes are regressed on variables measured as of the year the school year began (e.g., school year 2008 to 2009 revenue changes are regressed on 2007 to 2008 changes in Net Digest, income, and population). For the same reason, dummy and interaction variables indicating periods since the housing crisis began apply to school years ending June 2008 and June 2009. The income variable, as above, is the percent change in per capita personal income calculated from U.S. Bureau of Economic Analysis data. Income data are not available for the city school districts, so for regressions including an income variable, we use only the 159 county school systems' data. Population data for the corresponding county or city are from the Bureau of the Census. We do not have a direct measure of property market values for school districts or of the physical stock of property improvements. However, the property tax base grows from market value changes 
and from the addition of new homes, commercial buildings, and improvements to existing property, while the physical stock of buildings and improvements tends to grow with population. We therefore measure the change in property values using the percent change in the per capita property tax base. The per capita tax base is calculated from the reported Net Digest from the Georgia Department of Revenue, with population data from the Bureau of the Census.

Table 3 presents results of these regressions, beginning with an OLS regression using all 180 districts (and excluding the income variable) followed by OLS, PCSE, and fixed effects models using the 159 county systems. Comparing the two OLS models or the two PCSE models, we see that omitting the city school systems in order to include an income variable does not result in materially different estimates for the coefficients on per capita Net Digest or population. The estimates from the first fixed effect model are also substantially the same as in the OLS and the PCSE pooled models.

The coefficient estimates of 0.26 to 0.29 (all significant at the 1 percent level) on per capita Net Digest changes in Table 3 suggest that a 1 percent increase in property values per capita is associated with an increase in local source revenues of slightly less than 0.3 percent. This coefficient value is slightly higher than, but consistent with, the estimated effect of home values on property tax revenues in the regressions using QCD. The coefficient estimates for population changes of slightly more than one (also significant at the 1 percent level) are also consistent with the OLS and PCSE models using the QCD data, and suggest a roughly unitelastic response of local source revenues to population changes. Similarly, estimates on per capita income changes are also consistent with the QCD results in that they are not statistically significant in the OLS and PCSE pooled models or in the first fixed effects model. 
The one variable that is not in the QCD regressions is state funding of local districts. Prior research has shown that local source funding of schools, aggregated at the state level, responds negatively to changes in state source funding as school districts apparently compensate for changes in state transfers (Alm, Buschman, and Sjoquist, 2009). As a result, with data available on the district level in Georgia, we control for state funding of local districts in the Georgia regressions. We measure this by the percentage change in total state funding to the local school district. The results in Table 3 for this variable are not statistically significant.

Adding the interaction terms in column 6 of Table 3 for the 2008 and 2009 school years produces some similar and some different results relative to those from the regressions using the QCD data. First, as with the QCD data, the interaction term on population produces a significantly negative coefficient estimate of roughly one; we are unable to reject the null hypothesis that the sum of the coefficients on population and the interaction term is equal to zero, suggesting that local revenues ceased responding to population growth in the latest two school years. Second, however, and unlike the QCD results, adding the interaction terms leaves the coefficient estimate on the tax base essentially unchanged and still significantly positive. Finally, where the QCD fixed effects models found a marginally significant positive effect from income growth once the post-2006 interaction terms are included, the income interaction term in the Georgia model of Table 3 now has a negative $(-0.37)$ and highly significant (at the 1 percent level) estimate. One possible explanation is that, while year-to-year changes in per capita income do not generally affect school system revenue (i.e., the coefficient on per capita income is not significant), the lagged income variable continued to rise on average through 2008 while revenue fell on average in the final year, resulting in a spurious negative correlation in later periods. 
Finally, to estimate the effect of changes in the property tax base on the choice of property tax rates, we regress the percent change in millage rates on the percent changes in the per capita Net Digest and the prior year's percent changes in population and per capita income, along with a dummy variable for school years ending 2008 and 2009. Note that there is some evidence from other studies that tax rates are determined in a largely mechanical way based on overall revenue requirements once other components of the property tax are determined (Anderson, 2006). If this is an accurate description of the property tax system in Georgia, then estimating the determinants of the property tax rate involve estimating an identify. However, as noted above, in Georgia school district officials actually have discretion in setting property tax rates. In this case, the regression results with the percent change in millage rates as the dependent variable give some information on the causal factors in tax rate changes. ${ }^{17}$

Table 4 presents results from these OLS, PCSE, and fixed effects regressions. These results are consistent across the three estimation methods with coefficient estimates on the per capita Net Digest between -0.30 and -0.34 , all significant at the 1 percent level. Estimates on the income, population, and dummy variables are not statistically significant. Specifications using an interaction term (the post-2007 dummy times the Net Digest change) instead of the dummy variable do not materially alter the results; that is, the response of Georgia school districts in their choice of tax rates to changes in the Net Digest does not appear to have changed since the housing crisis began. Districts continue to partially offset increases (decreases) in the tax base with lower (higher) tax rates with an elasticity of around -0.3. In addition, we control for changes in student enrollment (also lagged as millage rates are set before enrollment is known) and, as in the Table 3 regressions, changes in state funding. While enrollment changes do not

${ }^{17}$ We are indebted to Dan McMillen for helping us to clarify our thinking on this issue. 
appear to have a significant effect on tax rate decisions, changes in state funding have a negative effect on millage rates.

\section{Conclusions: Whither the Property Tax?}

Using data from the Department of the Census on the trends of local government revenues (especially the property tax) over the last decade, we find that there is great diversity in the experiences of local governments across the United States over this period and especially in the immediate past several years. However, we also find that the widespread expectation that most local governments have suffered the same fate as state and federal governments is not generally supported, at least to date. Indeed, large numbers of local governments have continued to experience increases in property tax revenues, some quite significant, even in the face of the bursting of the housing bubble and the national recession. Focusing more specifically on the State of Georgia, we see that local governments in Georgia have seen property tax revenues increase by 0.75 percent between 2008 and 2009, following increases of 5.72 percent and 3.19 percent in the immediately preceding two years. Detailed data on housing values, property tax assessments and property tax rates for local governments in the state show that property values declined in Georgia (as in many other parts of the country), but that local governments were in many cases able to maintain a fairly steady pattern of collections by increasing millage rates. As with national trends, the Georgia patterns may well change as property value declines force reactions by local governments. However, to date any declines in property tax revenues seem isolated and due to very specific local developments.

Our estimation results, both for our national and for our Georgia datasets, indicate that these changes in property tax revenues are driven primarily by population growth and the 
physical growth of the tax base that comes with it. Changes in property market values are clearly a factor, but only partially, as local governments sometimes offset changes in property values by adjusting millage rates in the opposite direction. In the short run at least, income effects have ambiguous effects, and property tax limitations do not appear to be an important consideration.

Given these findings, it is natural and important to ask how should a local government determine its local tax policies? There are a variety of ways that have been used to answer this basic question, including what might be termed an "optimal tax" approach (Gordon, 1983), a "portfolio" approach (White, 1983; Misiolek and Perdue, 1987; Gentry and Ladd, 1994), a "tax smoothing" approach (Perdue, 1992), a "political economy" approach (Hettich and Winer, 1999), or a “tax assignment” approach (Musgrave, 1983; McLure, 1998; Bird, 2000), among others. In all cases, the appropriate tax structure represents a tradeoff between conflicting goals (e.g., efficiency, equity, adequacy, growth, stability, simplicity, electability), chosen subject to various constraints (e.g., achieving a revenue target, minimizing revenue volatility, meeting distributional requirements, satisfying constituents).

In this context, local government reliance on the property tax has both strengths and weaknesses. As argued especially by Mieszkowski and Zodrow (1989) and more recently by Zodrow (2001) in their comprehensive surveys of the property tax literature, the tax seems likely to have a somewhat progressive impact on the distribution of income, and it may also have relatively small distortive effects. However, it is also quite visible to those who must pay the tax, it is difficult to administer, and it is an inelastic source of revenues (Oates, 2001). Indeed, the property tax is often portrayed as an unpopular, hard-to-administer, and inelastic tax. However, this last feature in particular has proven an important advantage in the recent recession. Indeed, local government reliance on the property tax rather than more elastic revenues sources like 
income, sales, and excise taxes has - so far, in any event - helped local governments to avoid some of the more severe difficulties experience by many other governments in the current economic situation. Given the institutional realities of its administration, it may take several assessment cycles (e.g., years) before changes in market values of properties are accurately reflected in assessed values and, ultimately, in property tax collections. Further, local jurisdictions routinely adjust millage rates to bring revenues in line with expenditures. This feature is of course available for other taxes, but it seems a more common - and politically viable - occurrence for the local property. Local government reliance on the property tax is likely to continue in at least some form for the immediate future, and we believe that our results suggest that this reliance should not be discouraged. 


\section{$\underline{\text { References }}$}

Alm, James, Robert D. Buschman, and David L. Sjoquist (2009). "Economic Conditions and State and Local Education Revenue". Public Budgeting \& Finance 29 (3): 28-51.

Anderson, John E. (2010). "Shocks to the Property Tax Base and Implications for Local Public Finance". Paper presented at the Urban Institute-Brookings Institution Tax Policy Center and the Lincoln Institute of Land Policy Conference, "Effects of the Housing Crisis on State and Local Governments". Washington, D.C.

Anderson, Nathan B. (2006). "Property Tax Limitations: An Interpretative Review". National Tax Journal 59 (3): 685-694.

Attanasio, Orazio, Laura Blow, Robert Hamilton, and Andrew Leicester (2009). "Booms and Busts: Consumption, House Prices and Expectations”. Economica 76 (301): 20-50.

Bird, Richard M. (2000). "Rethinking Subnational Taxes: A New Look at Tax Assignment". Tax Notes International 20 (8 May 2000): 2069-2096.

Bourdeaux, Carolyn and Sungman Jun (2011). Comparing Georgia's Revenue Portfolio to Regional and National Peers, FRC Report 222. Atlanta, GA: Fiscal Research Center, Andrew Young School of Policy Studies, Georgia State University.

Bostic, Raphael, Stuart Gabriel, and Gary Painter (2009). "Housing Wealth, Financial Wealth, and Consumption: New Evidence from Micro Data". Regional Science and Urban Economics 39 (1): 79-89.

Boyd, Donald J. and Lucy Dadayan (2009). "State Tax Decline in Early 2009 Was the Sharpest on Record". State Tax Notes 54 (3 August 2009): 305-325.

Boyd, Donald J. (2010). "Recession, Recovery, and State and Local Finances". Paper presented at the Urban Institute-Brookings Institution Tax Policy Center and the Lincoln Institute of Land Policy Conference, "Effects of the Housing Crisis on State and Local Governments". Washington, D.C.

Campbell, John Y. and Joao F. Cocco (2007). "How Do House Prices Affect Consumption? Evidence from Micro Data”. Journal of Monetary Economics 54 (3): 591-621.

Center on Budget and Policy Priorities (2010). "An Update on State Budget Cuts" (19 April 2010), available online at: http://www.cbpp.org/cms/index.cfm?fa=view\&id=1214.

Cornia, Gary C. and Lawrence C. Walters (2006). "Full Disclosure: Controlling Property Tax Increases During Periods of Increasing Housing Values”. National Tax Journal 59 (3): 735-749. 
Cutler, David, Douglas Elmendorf, and Richard Zeckhauser (1999). "Restraining the Leviathan: Property Tax Limitations in Massachusetts". Journal of Public Economics 71 (3): 31334.

Diaz, III, Julian (1990). "How Appraisers Do Their Work: A Test of the Appraisal Process and the Development of a Descriptive Model". The Journal of Real Estate Research 5 (1): 115.

Doerner, William M. and Keith R. Ihlanfeldt (2010). "House Prices and Local Government Revenues". Paper presented at the Urban Institute-Brookings Institution Tax Policy Center and the Lincoln Institute of Land Policy Conference, "Effects of the Housing Crisis on State and Local Governments". Washington, D.C.

Dye, Richard F. and Therese J. McGuire (1997). "The Effect of Property Tax Limitation Measures on Local Government Fiscal Behavior". Journal of Public Economics 66 (3): $469-487$.

Dye, Richard F., Therese McGuire, and Daniel P. McMillen (2005). “Are Property Tax Limitations More Binding over Time?" National Tax Journal 58 (2): 215-225.

Dye, Richard F., Daniel P. McMillen, and David F. Merriman (2006). "Illinois' Response to Rising Residential Property Values: An Assessment Growth Cap in Cook County". National Tax Journal 59 (3): 707-716.

Gentry, William M. and Helen F. Ladd (1994). "State Tax Structure and Multiple Policy Objectives". National Tax Journal 47 (4): 747-772.

Gordon, Roger H. (1983). "An Optimal Taxation Approach to Fiscal Federalism". The Quarterly Journal of Economics 98 (4): 567-586.

Haveman, Mark and Terri A. Sexton (2008). "Property Tax Assessment Limits: Lessons from Thirty Years of Experience". Policy Focus Report, Lincoln Institute of Land Policy. Boston, MA.

Hettich, Walter and Stanley L. Winer (1999). Democratic Choice and Taxation: A Theoretical and Empirical Analysis. Cambridge, UK: Cambridge University Press.

Hoyt, William H, Paul A. Coomes, and Amelia M. Biehl (2009). "Tax Limits, Houses, and Schools: Seemingly Unrelated and Offsetting Effects". IFIR Working Paper Series No. 2009-003, University of Kentucky. Lexington, KY.

Ladd, Helen and Julie Boatright Wilson (1982). "Why Voters Support Tax Limitations: Evidence from Massachusetts' Proposition 21/2”. National Tax Journal 35 (2): 121-148.

Lutz, Byron (2008). "The Connection Between House Price Appreciation and Property Tax Revenues". National Tax Journal 61 (3): 555-572. 
Lutz, Byron, Raven Molloy, and Hui Shan (2010). "The Housing Crisis and State and Local Government Tax Revenue: Five Channels". Paper presented at the Urban InstituteBrookings Institution Tax Policy Center and the Lincoln Institute of Land Policy Conference, "Effects of the Housing Crisis on State and Local Governments". Washington, D.C.

McAllister, Pat, Andrew Baum, Neil Crosby, Paul Gallimore, and Adelaide Gray (2003). "Appraiser Behavior and Appraisal Smoothing: Some Qualitative and Quantitative Evidence”. Journal of Property Research 20 (3): 261-280.

McLure, Charles E., Jr. (1998). "The Tax Assignment Problem: Ends, Means, and Constraints". Public Budgeting and Financial Management 9 (4): 652-683.

Mieszkowski, Peter and George R. Zodrow (1989). "Taxation and the Tiebout Model: The Differential Effects of Head Taxes, Taxes on Land Rents, and Property Taxes". The Journal of Economic Literature 27 (4): 1098-1146.

Mikesell, John L. and Daniel R. Mullins (2010). "State and Local Revenue Yield and Stability in the Great Recession”. State Tax Notes 55 (25 January 2010): 267-274.

Misiolek, Walter S. and D. Grady Perdue (1987). "The Portfolio Approach to State and Local Structures". National Tax Journal 40 (1): 111-114.

Musgrave, Richard A. (1983). "Who Should Tax, Where, and What?" In Tax Assignment in Federal Countries, Charles E. McLure, Jr., ed., 2-19. Canberra, Australia: Centre for Research on Federal Financial Relations.

O’Sullivan, Arthur, Terri A. Sexton, and Steven M. Sheffrin (1995). Property Taxes and Tax Revolts. Cambridge, UK: Cambridge University Press.

Oates, Wallace E. (ed.) (2001). Property Taxation and Local Government Finance. Cambridge MA: Lincoln Institute of Land Policy.

Office of Management and Budget (2012). Budget of the U.S. Government. Washington, D.C.: U.S. Government Printing Office.

Perdue, D. Grady (1992). "Tax Betas in State and Local Government Tax Structure Analysis". Public Budgeting and Financial Management 4 (2): 359-378.

Preston, Anne E., and Casey Ichniowski (1991). "A National Perspective on the Nature and Effects of the Local Property Tax Revolt, 1976-1986”. National Tax Journal 44 (2): 123145. 
Quan, Daniel. C. and John M. Quigley (1991). "Price Formation and the Appraisal Function in Real Estate Markets". The Journal of Real Estate Finance and Economics 4 (2): 127146.

The Nelson A. Rockefeller Institute of Government (2010). "Revenue Declines Less Severe, But States' Fiscal Crisis Is Far From Over" (April 2010, No. 79), available online at: http://www.rockinst.org/pdf/government_finance/state_revenue_report/2010-04-16SRR 79.pdf.

Rubenstein, Ross and David L. Sjoquist (2003). Financing Georgia's Schools: A Primer, FRC Report 87. Atlanta, GA: Fiscal Research Center, Andrew Young School of Policy Studies, Georgia State University.

Skidmore, Mark and Eric Scorsone (2010). "Causes and Consequences of Fiscal Stress in Michigan Municipal Governments". Paper presented at the Urban Institute-Brookings Institution Tax Policy Center and the Lincoln Institute of Land Policy Conference, "Effects of the Housing Crisis on State and Local Governments". Washington, D.C.

Wallin, Bruce A. (2004). "The Tax Revolt in Massachusetts: Revolution and Reason”. Public Budgeting \& Finance 24 (4): 34-50.

Wallin, Bruce and Jeffery Zabel (2010). "Property Tax Limitations and Local Fiscal Conditions: The Impact of Proposition $2 \frac{1}{2}$ in Massachusetts". Paper presented at the Urban InstituteBrookings Institution Tax Policy Center and the Lincoln Institute of Land Policy Conference, "Effects of the Housing Crisis on State and Local Governments". Washington, D.C.

White, Fred (1983). "Trade-off in Growth and Stability in State Taxes". National Tax Journal 36 (1): 103-114.

Wolverton, Marvin L. and Paul Gallimore (1999). "Client Feedback and the Role of the Appraiser”. Journal of Real Estate Research 18 (3): 415-431.

Zodrow, George R. (2001). "The Property Tax as a Capital Tax: A Room with Three Views". National Tax Journal 54 (1): 139-156. 
Chart 1. Percentage Change in Local Government Property Tax Collections, 2006-2007, by State (weighted)

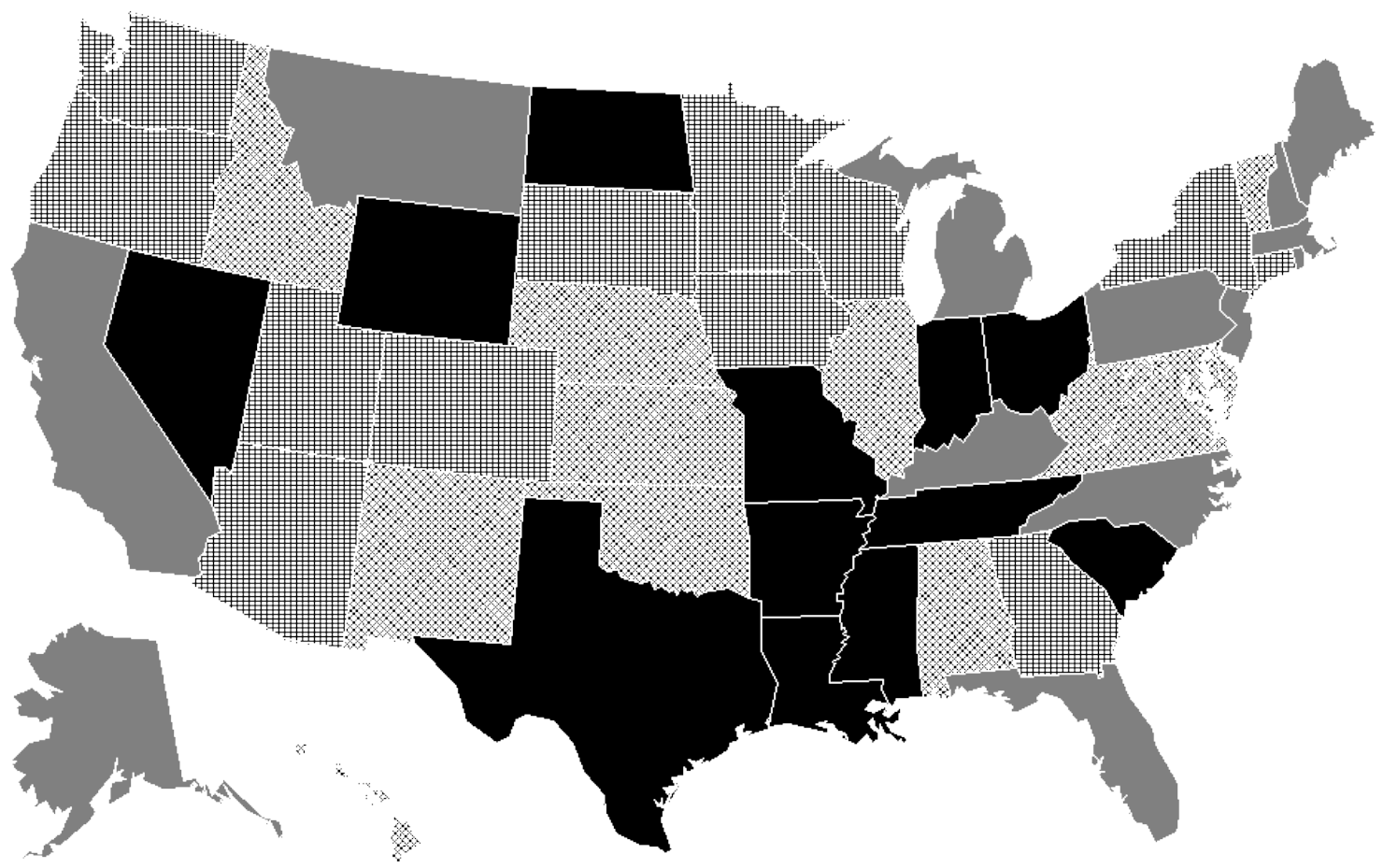

\% Change in Weighted Property Tax 2006-2007

$-13.00 \%-2.80 \%(12)$

㨫 $7.31 \%-11.00 \% \%(12)$

$2.81 \%-7.30 \%(13)$

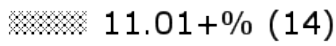


Chart 2. Percentage Change in Local Government Property Tax Collections, 2007-2008, by State (weighted)

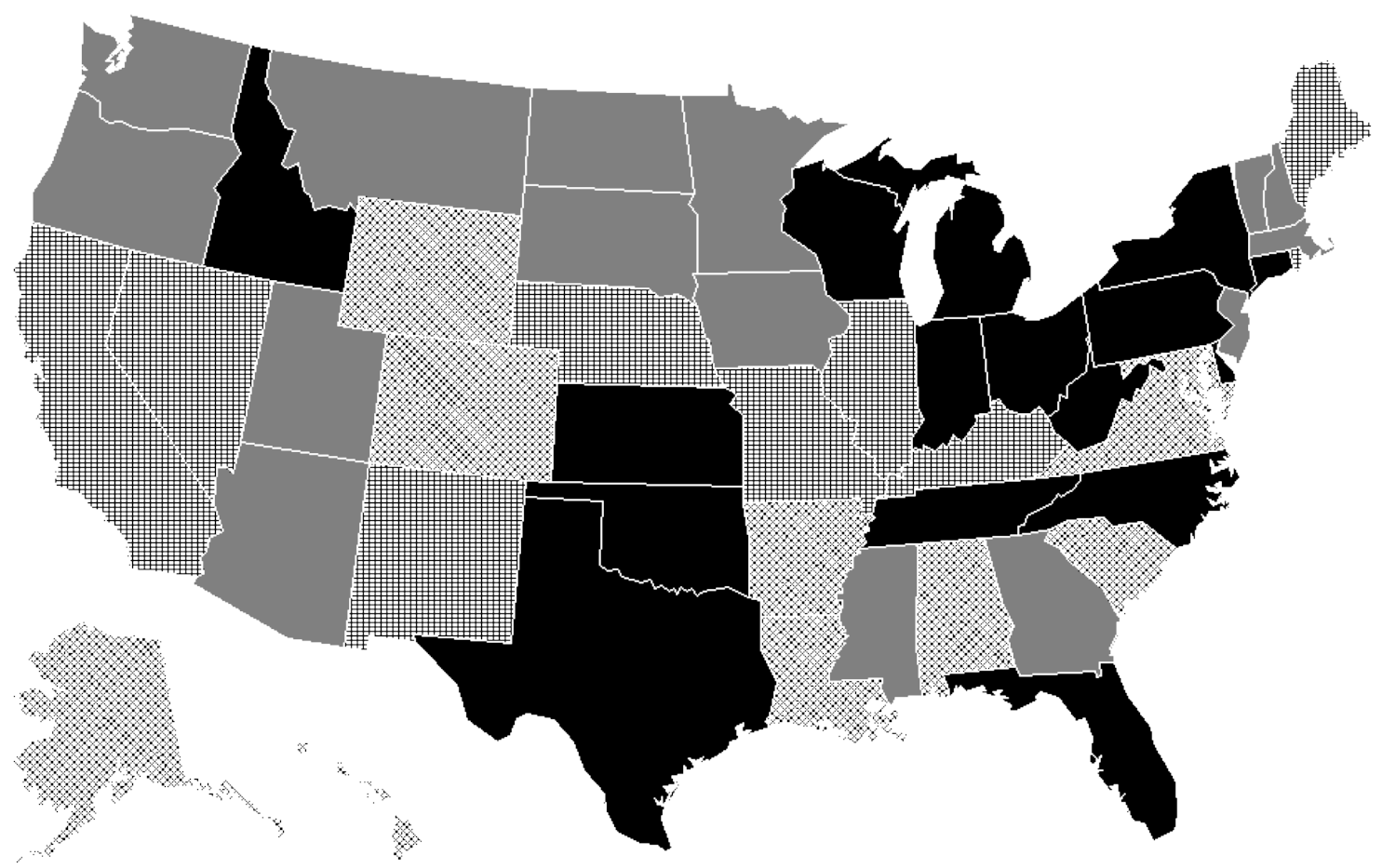

$\%$ Change in Weighted Property Tax 2007-2008

$-13.00 \%-2.80 \%(16)$

$2.81 \%-7.30 \%(15)$

7.31\%-11.00\%\% (9) 細 $11.01+\%(11)$ 
Chart 3. Percentage Change in Local Government Property Tax Collections, 2008-2009, by State (weighted)

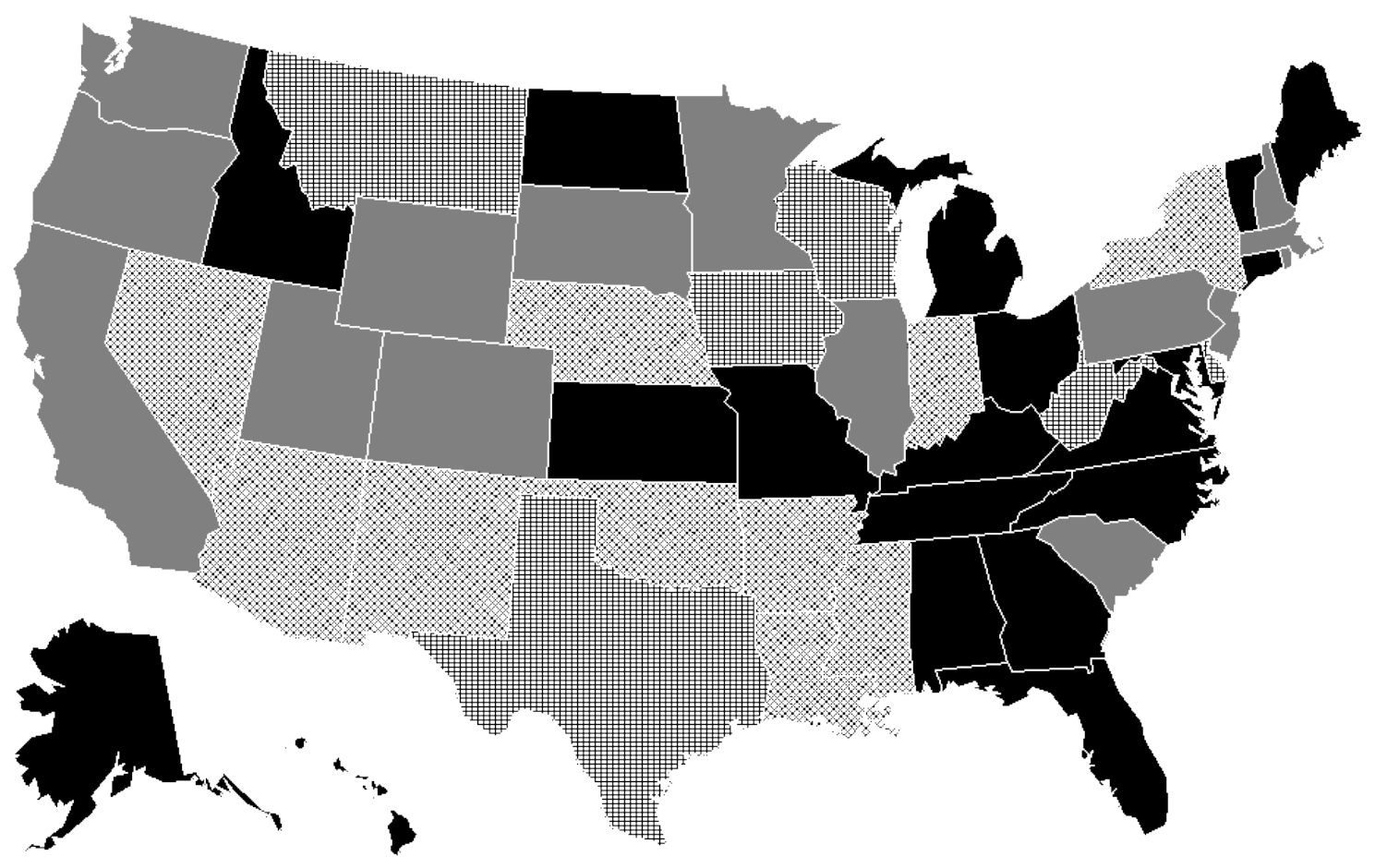

$\%$ Change in Weighted Property Tax 2008-2009

$-13.00 \%-2.80 \%(19)$

$$
2.81 \%-7.30 \%(16)
$$

7.31\%-11.00\%\%(6) 11.01+\%(10) 
Chart 4. Percentage Change in Local Government Property Tax Collections, 2006-2009, by State (weighted)

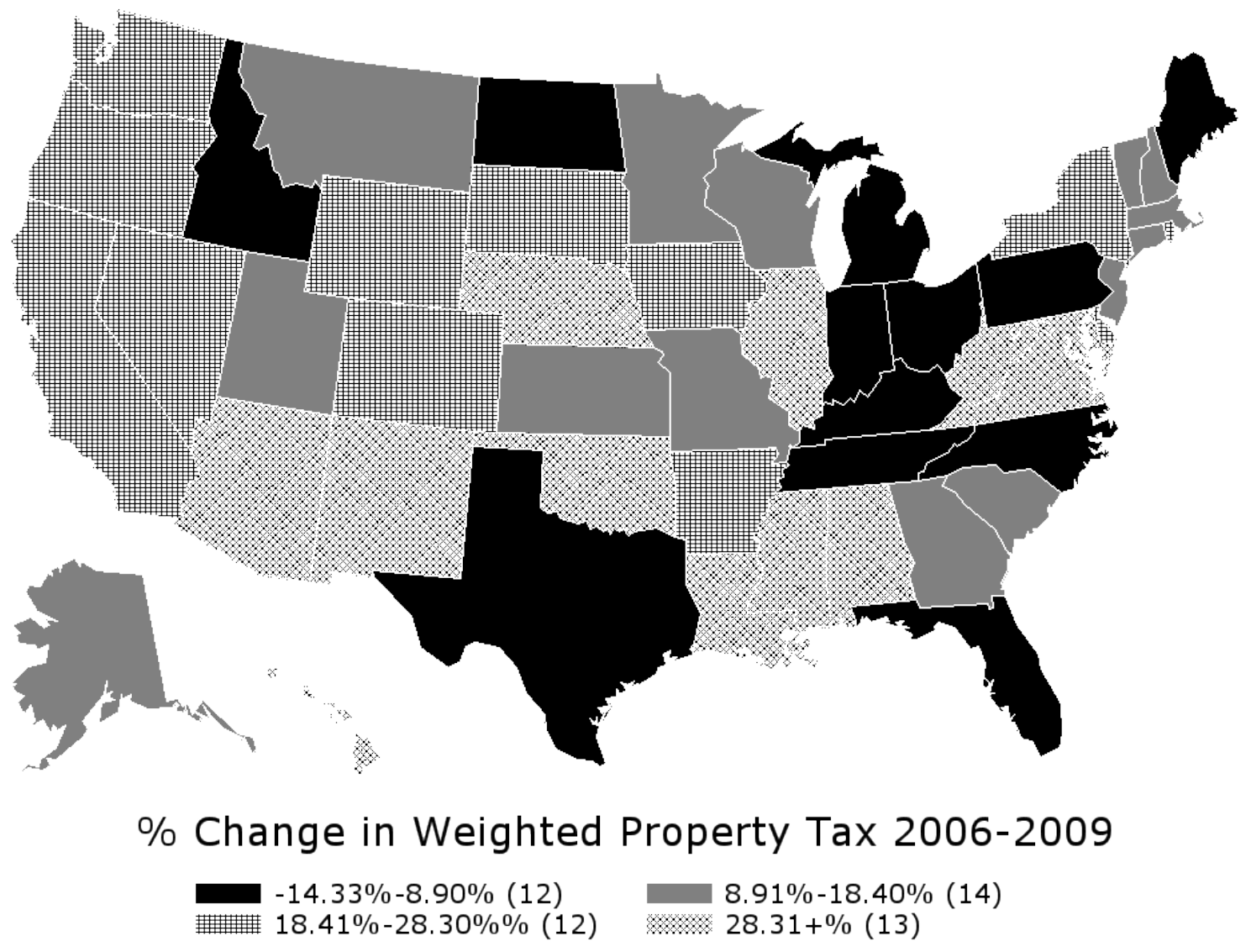


Figure 1. Local Government Real Property Tax Revenues, 1998 to 2009

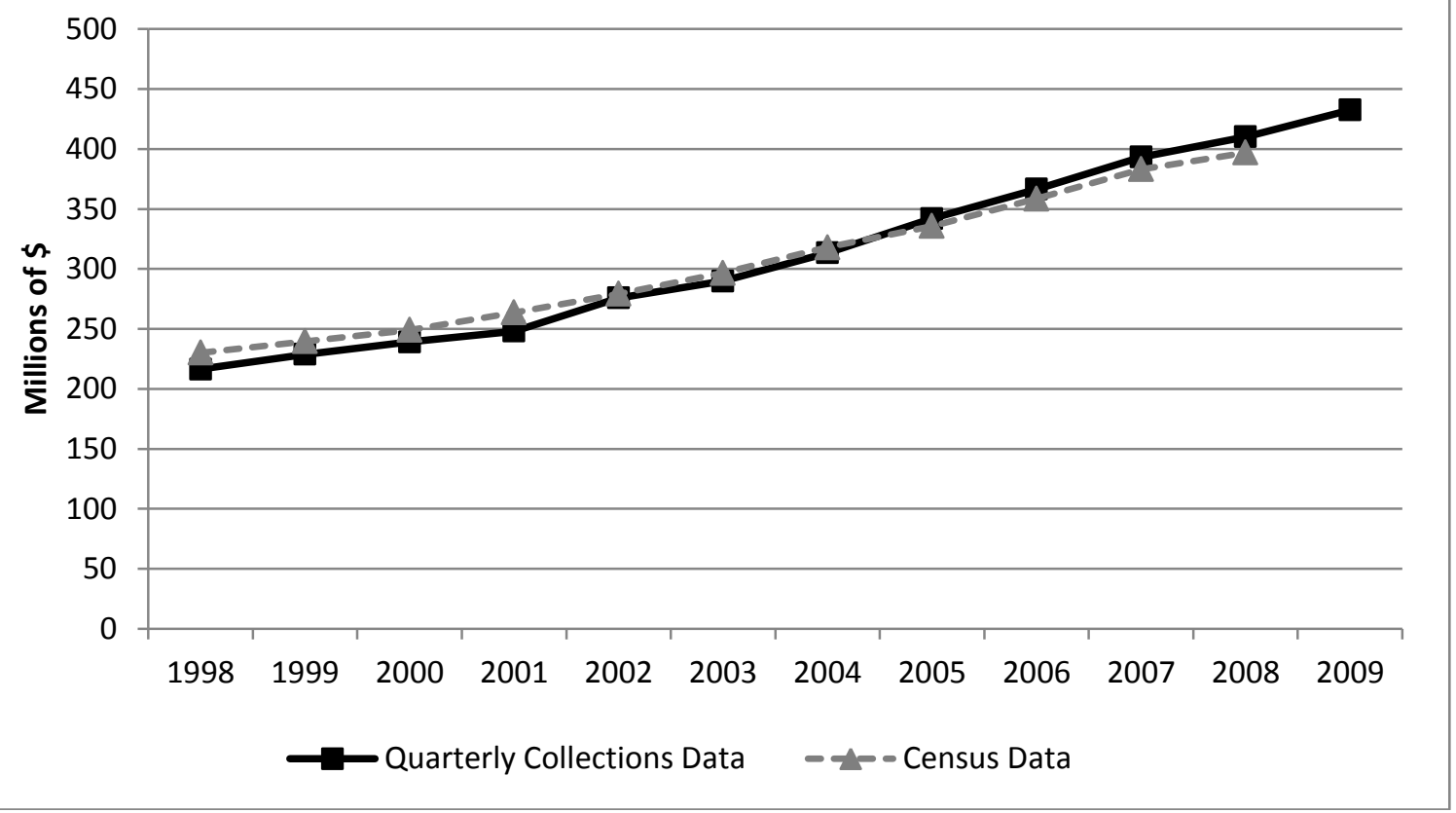

Figure 2. Annual Percentage Change in Local Government Real Property Tax Revenues, 1998 to 2009

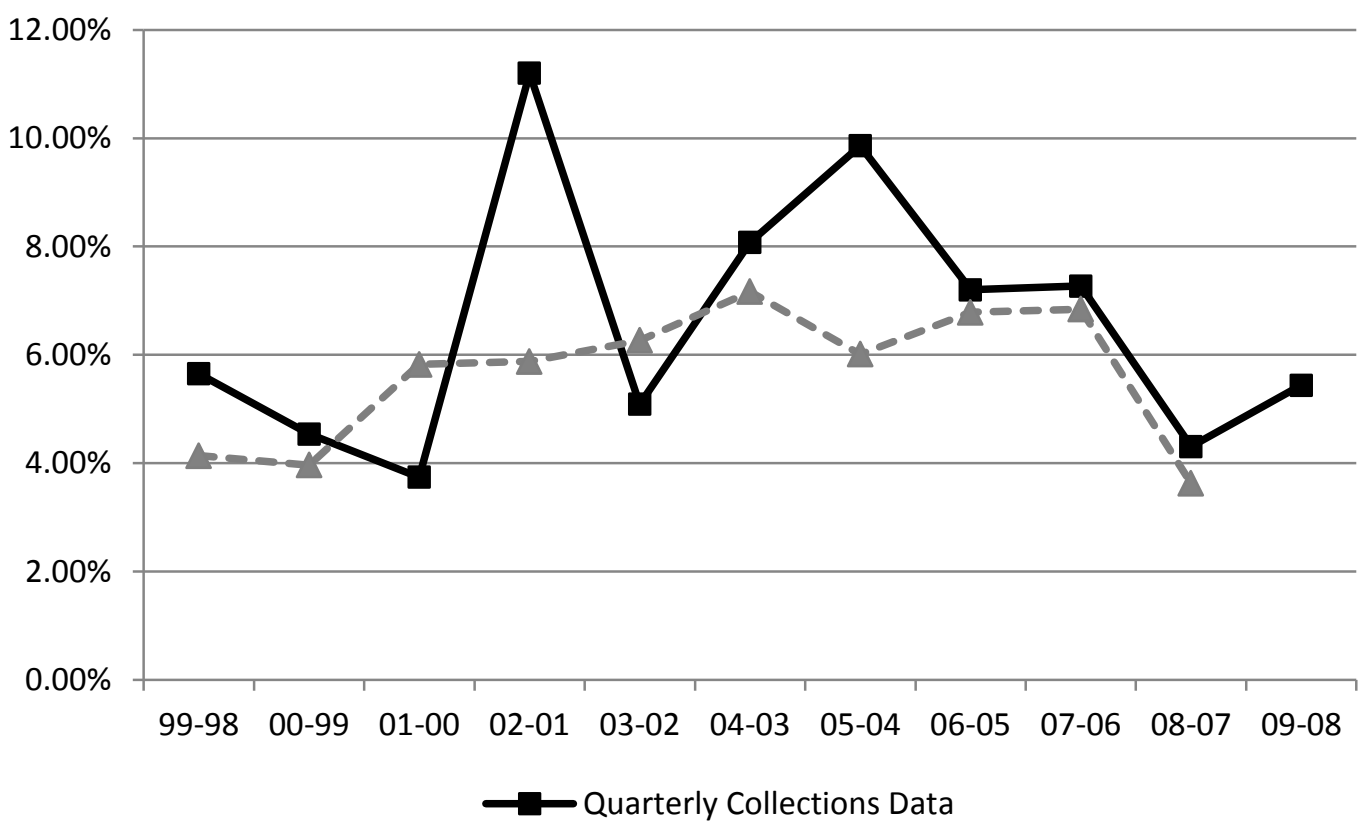


Figure 3. Local Government Real Property Tax Revenues Per Capita, 1998-2009

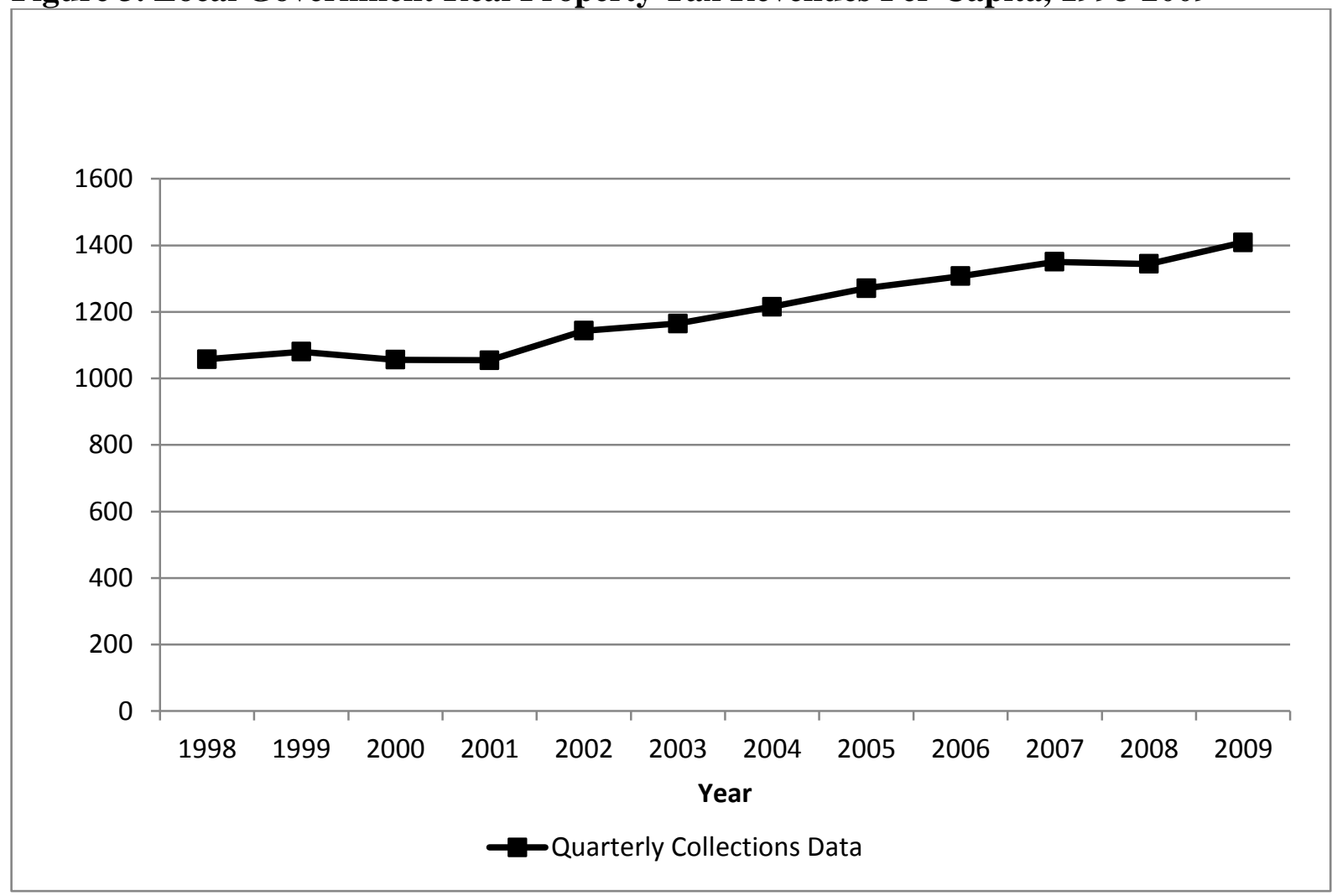

Figure 4. Growth in Georgia's Property Tax Base

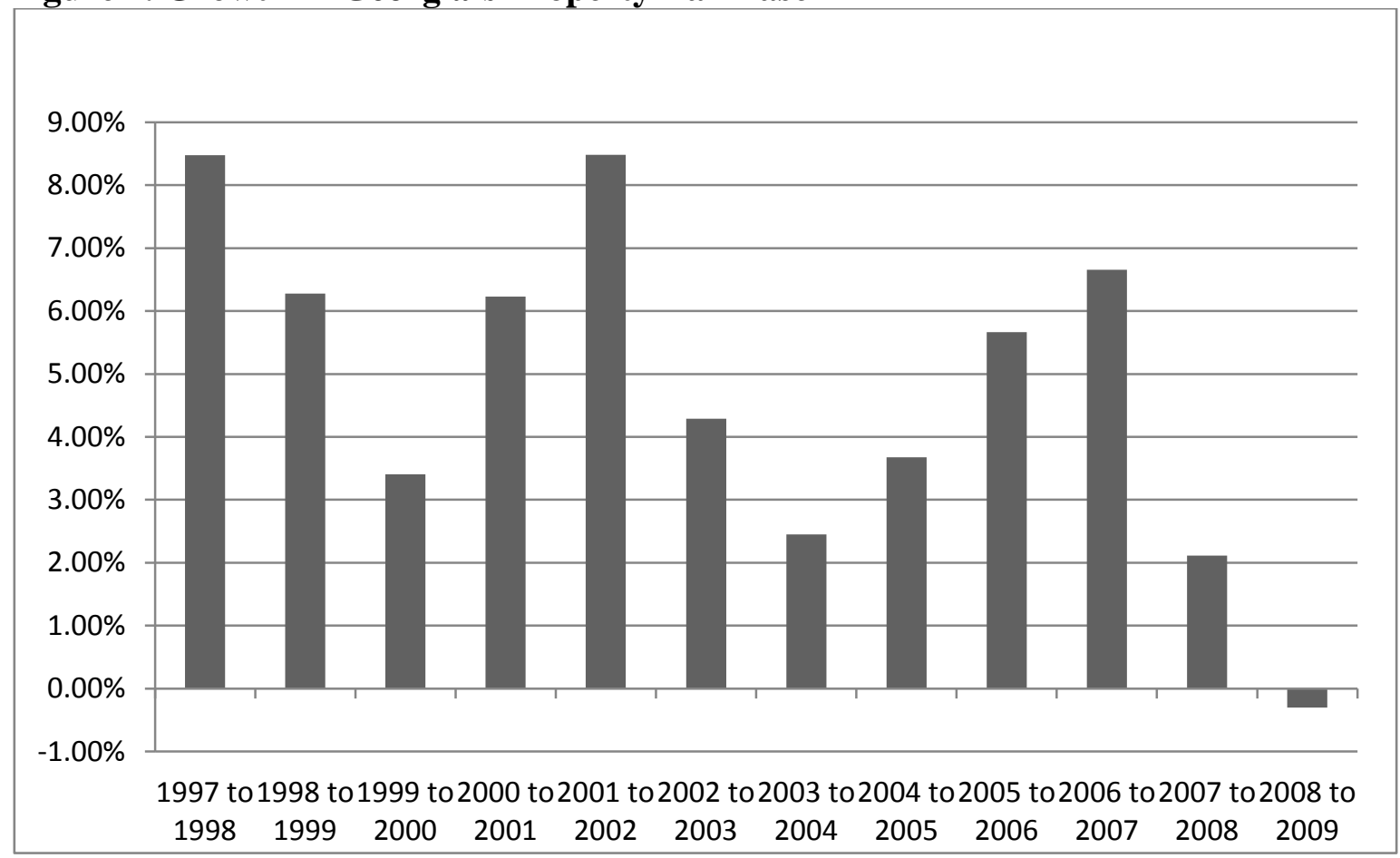


Figure 5. Growth in Georgia's Real Property Tax Base and Property Tax Liability

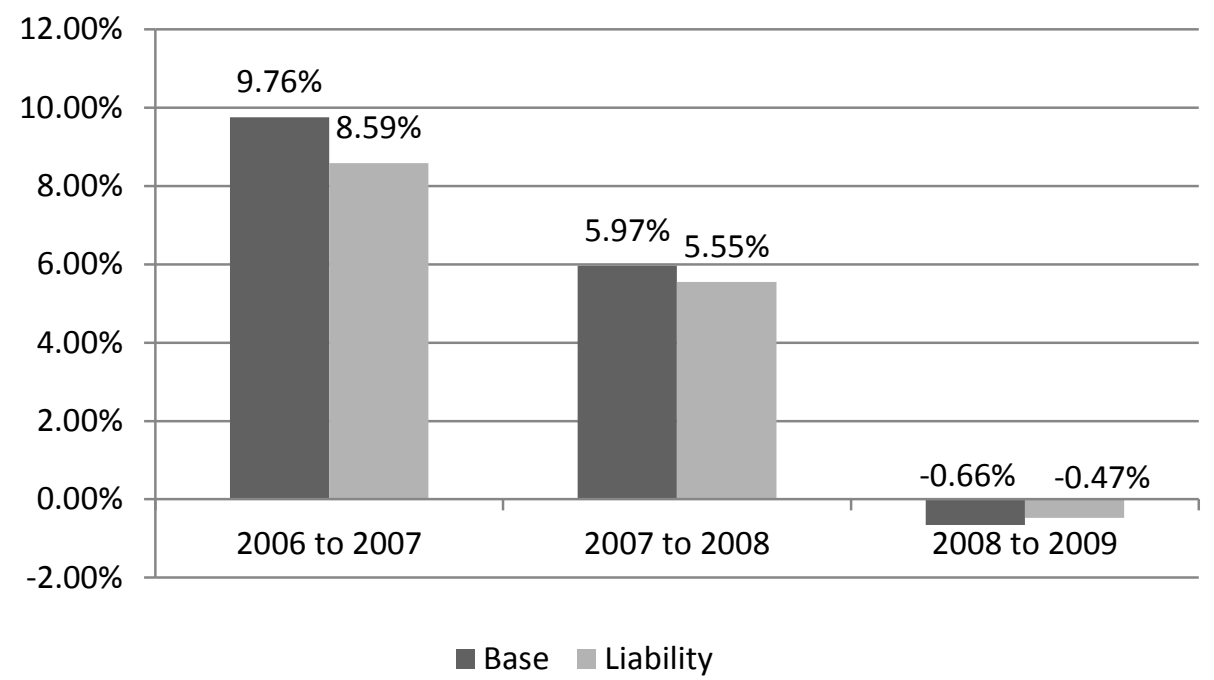

Figure 6. Percent Changes in Georgia's School Property Tax Base

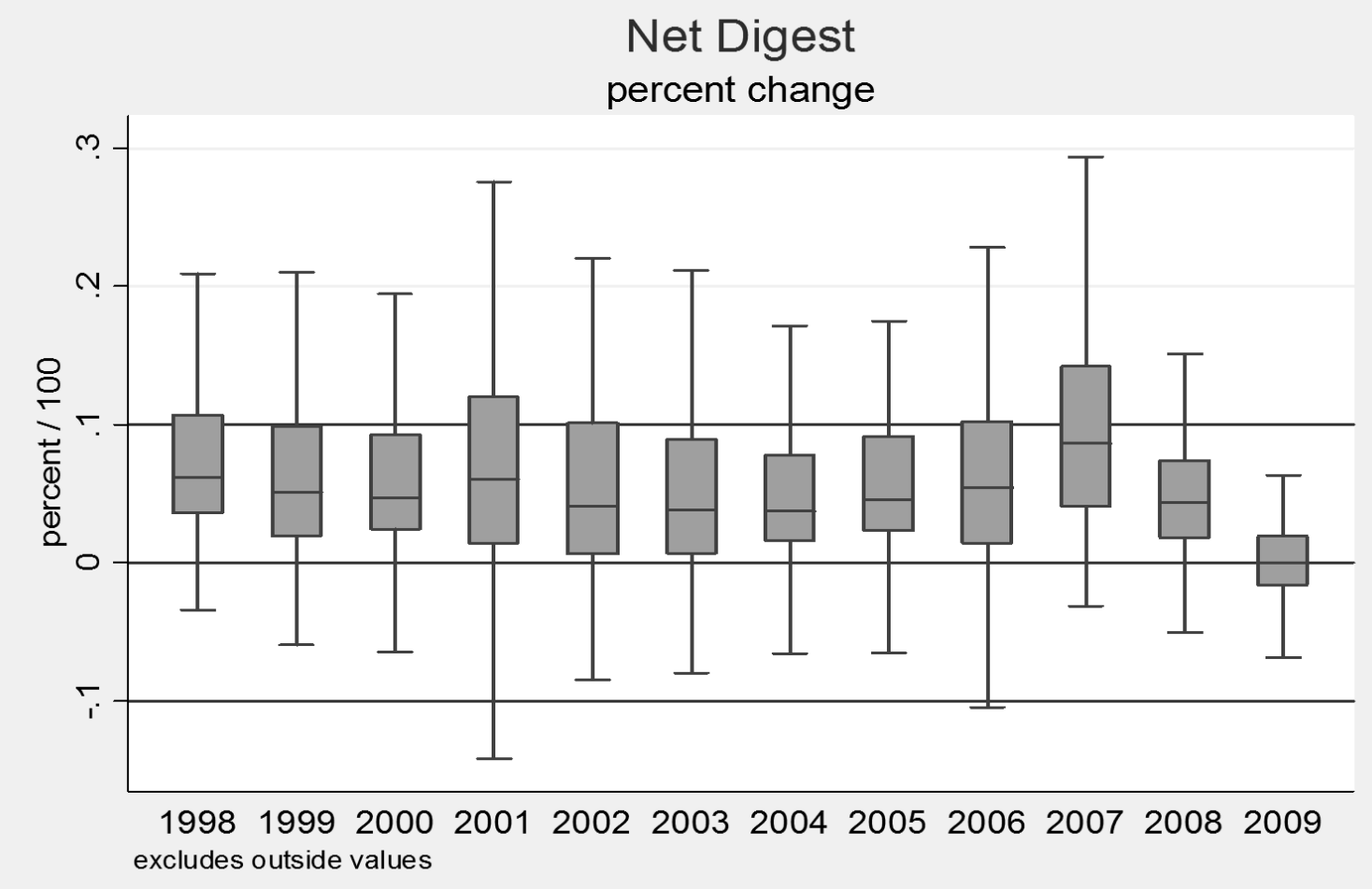


Figure 7. Changes in Property Tax Rates in Georgia School Districts

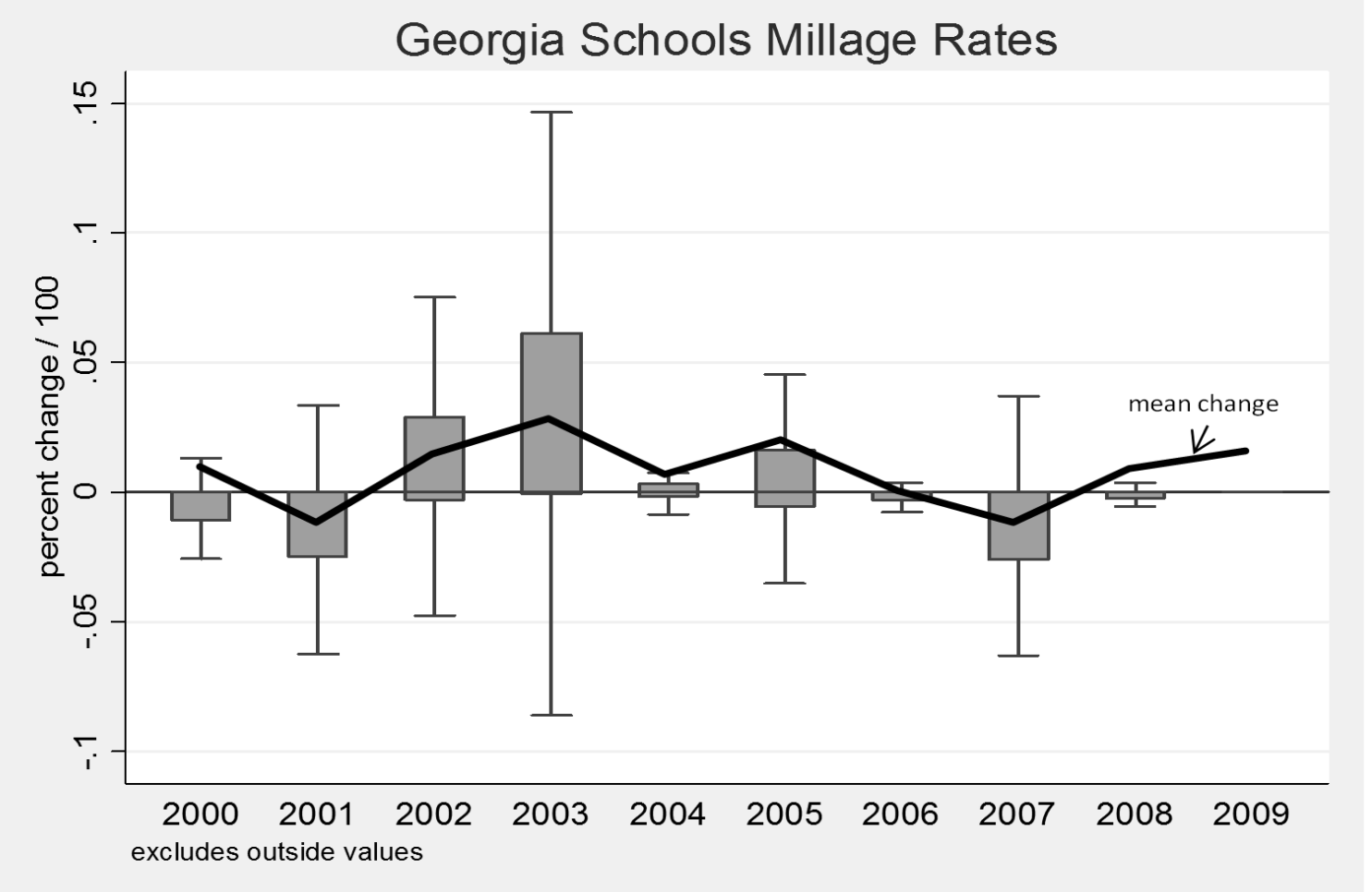

Figure 8. Simple Counts of Georgia Systems Changing Tax Rates

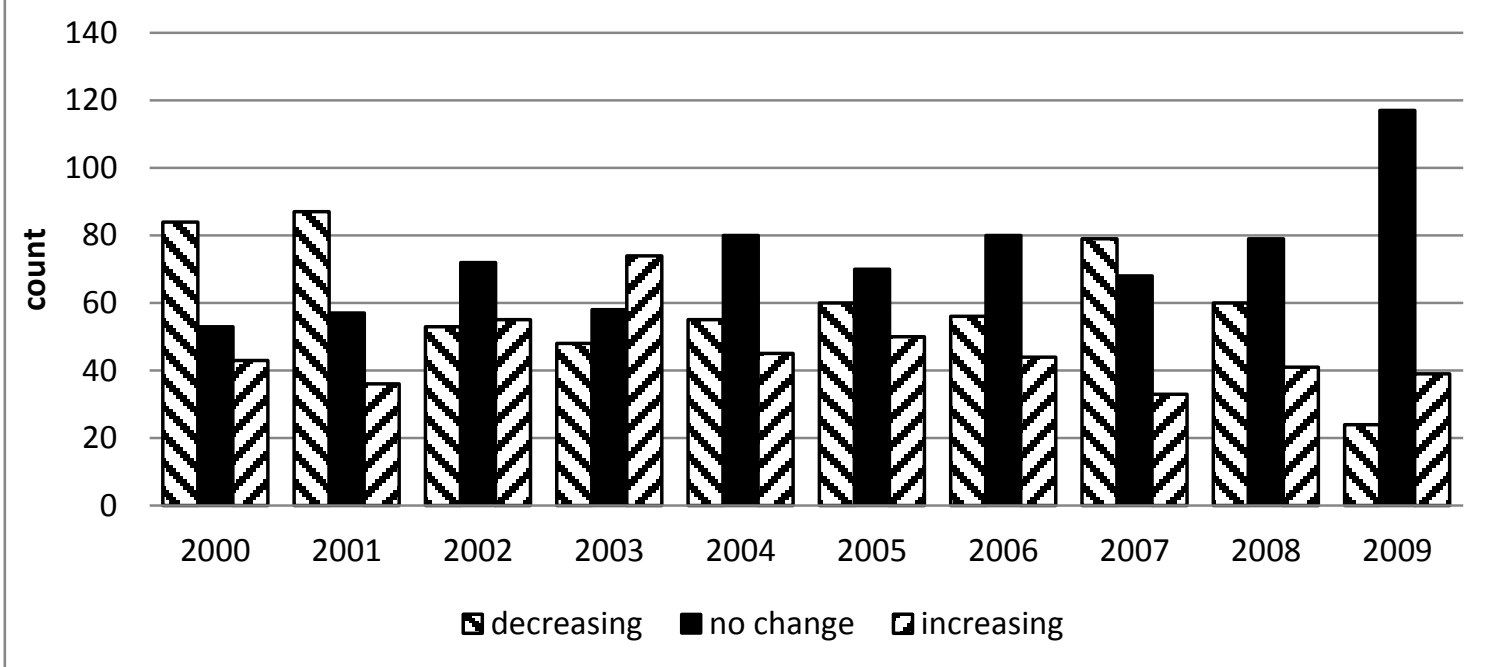


Figure 9. Correlation Between Tax Rate and Tax Base Changes in Georgia Systems

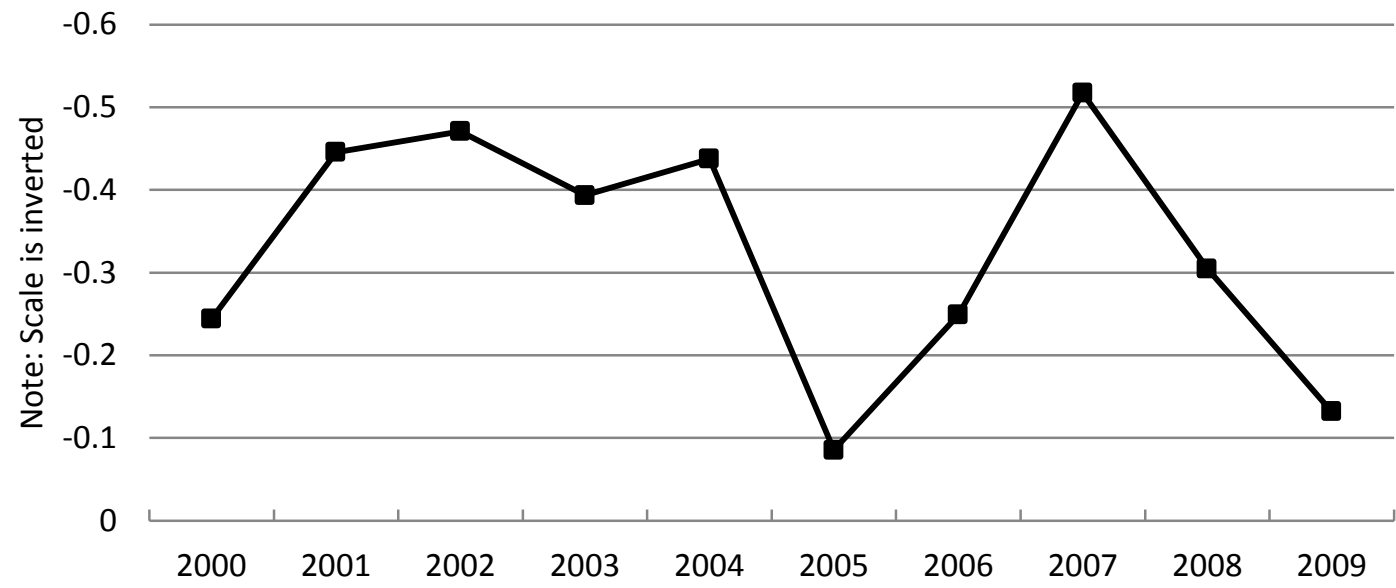

\section{Table 1. QCD Descriptive Statistics}

\begin{tabular}{|lccccc|} 
& \multicolumn{5}{c|}{ Standard } \\
Variable (1) & Observations & Mean & Deviation & Minimum Maximum \\
\hline All Units: & & & & & \\
Property Tax Revenue & 3564 & 0.1934 & 3.3095 & -1 & 151.25 \\
CMHPI & 3564 & 0.0540 & 0.0609 & -0.1488 & 0.2297 \\
Personal Income per capita & 3564 & 0.0385 & 0.0259 & -0.0579 & 0.1492 \\
Population & 3564 & 0.0040 & 0.0138 & -0.0787 & 0.1863 \\
Assessment Limits & 3564 & 0.4242 & 0.4943 & 0 & 1 \\
Restricted Dataset: (2) & & & & & \\
Property Tax Revenue & 2979 & 0.0659 & 0.1515 & -0.4493 & 0.9965 \\
CMHPI & 2979 & 0.0553 & 0.0625 & -0.1488 & 0.2297 \\
Personal Income per capita & 2979 & 0.0385 & 0.0260 & -0.0579 & 0.1492 \\
Population & 2979 & 0.0040 & 0.0131 & -0.0787 & 0.1126 \\
Assessment Limits & 2979 & 0.3988 & 0.4897 & 0 & 1 \\
\hline (1) Variables are percent change / 100, except for the assessment limits dummy variable. \\
(2) The restricted dataset excludes units with "excessive" revenue percentage changes in any year. \\
\hline
\end{tabular}




\begin{tabular}{|c|c|c|c|c|c|c|c|c|c|c|c|}
\hline & \multirow{2}{*}{\multicolumn{2}{|c|}{$\begin{array}{l}\text { All units } \\
\text { OLS (2) }\end{array}$}} & \multicolumn{8}{|c|}{ Restricted Dataset (1) } & \multirow{2}{*}{$\begin{array}{l}\text { Year }>2006 \\
\text { FE (4) }\end{array}$} \\
\hline & & & OLS (2) & & PCSE (3) & & $\mathrm{FE}(4)$ & & FE (4) & & \\
\hline CMHPI & -1.6099 & & 0.1269 & $* *$ & 0.1307 & $* * *$ & 0.1914 & $* * *$ & 0.1745 & & -0.1549 \\
\hline & $(1.171)$ & & $(0.056)$ & & $(0.048)$ & & $(0.061)$ & & $(0.109)$ & & $(0.155)$ \\
\hline Assessment Limits $\times$ CMHPI & 1.4515 & & 0.0901 & & 0.0950 & & 0.1322 & & 0.1536 & & -0.2769 \\
\hline & $(1.355)$ & & $(0.067)$ & & $(0.080)$ & & $(0.124)$ & & $(0.110)$ & & $(0.171)$ \\
\hline Post-2006 × CMHPI & & & & & & & & & $\begin{array}{c}-0.1263 \\
(0.309)\end{array}$ & & \\
\hline Personal Income Per Capita & $\begin{array}{c}-2.6242 \\
(2.152)\end{array}$ & & $\begin{array}{l}0.0829 \\
(0.107)\end{array}$ & & $\begin{array}{c}0.0348 \\
(0.138)\end{array}$ & & $\begin{array}{l}0.1629 \\
(0.160)\end{array}$ & & $\begin{array}{l}0.1885 \\
(0.165)\end{array}$ & & $\begin{array}{l}0.9493 \quad * * \\
(0.412)\end{array}$ \\
\hline Post-2006 $\times$ Personal Income Per C & apita & & & & & & & & $\begin{array}{c}-0.0283 \\
(0.326)\end{array}$ & & \\
\hline Population & $\begin{array}{l}1.1745 \\
(4.027)\end{array}$ & & $\begin{array}{l}1.1063 \\
(0.212)\end{array}$ & $* * *$ & $\begin{array}{l}1.1461 \\
(0.254)\end{array}$ & $* * *$ & $\begin{array}{l}0.7455 \\
(0.322)\end{array}$ & $* *$ & $\begin{array}{l}0.9287 \\
(0.298)\end{array}$ & $* * *$ & $\begin{array}{c}-0.0289 \\
(0.982)\end{array}$ \\
\hline Post-2006 $\times$ Population & & & & & & & & & $\begin{array}{c}-0.9124 \\
(0.422)\end{array}$ & $* *$ & \\
\hline Constant & $\begin{array}{l}0.3581 \\
(0.116) \\
\end{array}$ & $* * *$ & $\begin{array}{c}0.0477 \\
(0.006)\end{array}$ & $* * *$ & $\begin{array}{l}0.0491 \\
(0.008) \\
\end{array}$ & $* * *$ & $\begin{array}{l}0.0409 \\
(0.008)\end{array}$ & $* * *$ & $\begin{array}{l}0.0411 \\
(0.010) \\
\end{array}$ & $* * *$ & $\begin{array}{c}0.0057 \\
(0.016)\end{array}$ \\
\hline Observations & 3564 & & 2979 & & 2979 & & 2979 & & 2979 & & 993 \\
\hline Units & 396 & & 331 & & 331 & & 331 & & 331 & & 331 \\
\hline Periods & 9 & & 9 & & 9 & & 9 & & 9 & & 3 \\
\hline $\begin{array}{l}\text { F-test } / X^{2} \text { test (joint signif.), p-value } \\
\text { Rho }\end{array}$ & 0.4223 & & 0.0000 & & $\begin{array}{r}0.0000 \\
-0.1317\end{array}$ & & 0.0004 & & 0.0003 & & 0.0267 \\
\hline R-squared & 0.0011 & & 0.0137 & & 0.0176 & & 0.0116 & & 0.0134 & & 0.0085 \\
\hline
\end{tabular}




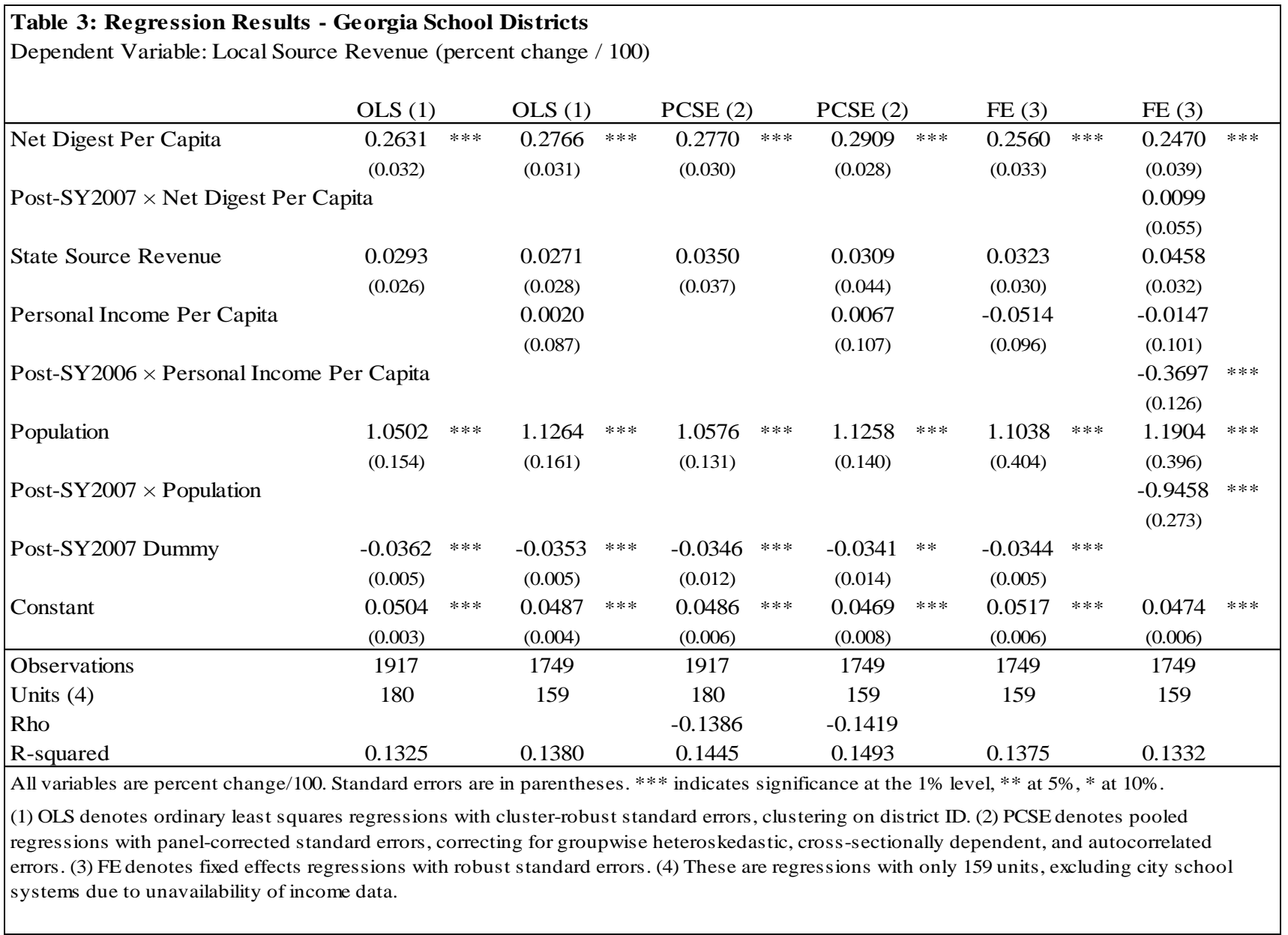




\begin{tabular}{|c|c|c|c|c|c|c|c|c|}
\hline $\begin{array}{l}\text { Table 4: Regression Resu } \\
\text { Dependent Variable: Millage }\end{array}$ & $\begin{array}{l}\text { lts - Geol } \\
\text { Rate (per }\end{array}$ & $\begin{array}{l}\text { gia } \\
\text { cent }\end{array}$ & $\begin{array}{l}\text { chool Dis } \\
\text { hange / } 10\end{array}$ & $\begin{array}{l}\text { tric } \\
0)\end{array}$ & & & & \\
\hline & OLS (1) & & OLS (1) & & PCSE (2) & & FE (3) & \\
\hline Net Digest Per Capita & $\begin{array}{c}-0.2983 \\
(0.031)\end{array}$ & $* * *$ & $\begin{array}{c}-0.3224 \\
(0.032)\end{array}$ & $* * *$ & $\begin{array}{l}-0.3226 \\
(0.022)\end{array}$ & $* * *$ & $\begin{array}{c}-0.3369 \\
(0.033)\end{array}$ & $* * *$ \\
\hline State Source Revenue & $\begin{array}{c}-0.0373 \\
(0.015)\end{array}$ & $* *$ & $\begin{array}{c}-0.0304 \\
(0.016)\end{array}$ & $*$ & $\begin{array}{c}-0.0300 \\
(0.025)\end{array}$ & & $\begin{array}{c}-0.0295 \\
(0.017)\end{array}$ & $*$ \\
\hline Students & $\begin{array}{l}0.0692 \\
(0.047)\end{array}$ & & $\begin{array}{l}0.0236 \\
(0.044)\end{array}$ & & $\begin{array}{l}0.0236 \\
(0.063)\end{array}$ & & $\begin{array}{c}0.0142 \\
(0.058)\end{array}$ & \\
\hline Personal Income Per Capita & & & $\begin{array}{c}-0.0169 \\
(0.061)\end{array}$ & & $\begin{array}{c}-0.0171 \\
(0.070)\end{array}$ & & $\begin{array}{c}-0.0574 \\
(0.063)\end{array}$ & \\
\hline Population & $\begin{array}{c}-0.0388 \\
(0.078)\end{array}$ & & $\begin{array}{c}-0.0381 \\
(0.082)\end{array}$ & & $\begin{array}{c}-0.0394 \\
(0.100)\end{array}$ & & $\begin{array}{c}-0.0009 \\
(0.140)\end{array}$ & \\
\hline Post-SY2007 Dummy & $\begin{array}{c}-0.0077 \\
(0.004)\end{array}$ & $*$ & $\begin{array}{c}-0.0074 \\
(0.005)\end{array}$ & & $\begin{array}{c}-0.0073 \\
(0.007)\end{array}$ & & $\begin{array}{c}-0.0078 \\
(0.005)\end{array}$ & $*$ \\
\hline Constant & $\begin{array}{l}0.0277 \\
(0.003) \\
\end{array}$ & $* * *$ & $\begin{array}{l}0.0289 \\
(0.003) \\
\end{array}$ & $* * *$ & $\begin{array}{c}0.0289 \\
(0.004) \\
\end{array}$ & $* * *$ & $\begin{array}{c}0.0307 \\
(0.004) \\
\end{array}$ & $* * *$ \\
\hline Observations & 1758 & & 1590 & & 1590 & & 1590 & \\
\hline Units (4) & 180 & & 159 & & 159 & & 159 & \\
\hline Periods & & & & & 10 & & 10 & \\
\hline Rho & & & & & 0.0092 & & & \\
\hline R-squared & 0.1087 & & 0.1662 & & 0.1666 & & 0.1658 & \\
\hline $\begin{array}{l}\text { All variables are percent change } \\
* * * \text { indicates significance at the } \\
\text { (1) OLS denotes ordinary least s } \\
\text { district ID. (2) PCSE denotes po } \\
\text { groupwise heteroskedastic, cros } \\
\text { fixed effects regressions with ro } \\
\text { excluding city school systems d }\end{array}$ & $\begin{array}{l}\text { / 100. Stan } \\
1 \% \text { level, } \\
\text { quares regr } \\
\text { led regress } \\
\text { s-sectional } \\
\text { oust standa } \\
\text { ue to unava }\end{array}$ & $\begin{array}{l}\text { dard } \\
* \text { at } \\
\text { essio } \\
\text { ions } \\
\text { ly dep } \\
\text { ard err }\end{array}$ & $\begin{array}{l}\text { rors are in } \\
\%, * \text { at } 10 \% \\
\text { s with clus } \\
\text { ith panel-c } \\
\text { endent, anc } \\
\text { rs. (4) The } \\
\text { y of incom }\end{array}$ & $\begin{array}{l}\text { Darent } \\
\text { er-rot } \\
\text { orrect } \\
\text { auto } \\
\text { e are }\end{array}$ & $\begin{array}{l}\text { eses. } \\
\text { ust standarc } \\
\text { d standard } \\
\text { orrelated err } \\
\text { egressions }\end{array}$ & $\begin{array}{l}\text { d erro } \\
\text { error } \\
\text { rors. } \\
\text { with }\end{array}$ & $\begin{array}{l}\text { clustering } \\
\text { correcting } \\
\text { FE denote } \\
\text { ly } 159 \text { unit }\end{array}$ & $\begin{array}{l}\text { on } \\
\text { for } \\
\text { s, }\end{array}$ \\
\hline
\end{tabular}

